\title{
Magnetic fabrics and microstructures of Paleoproterozoic intrusive bodies of Piedra Alta Terrane, Río de la Plata Craton, Uruguay: a reconnaissance study
}

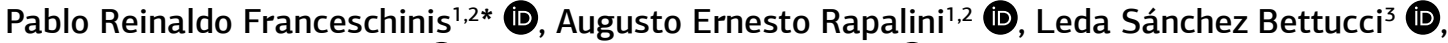 \\ Carmen Martínez Dopico ${ }^{1,2}$ (D), Florencia Nidia Milanese ${ }^{1,2}$ (D)
}

\begin{abstract}
Small to medium-sized intrusive bodies with ages between 2.1 and 2.0 Ga characterize Piedra Alta terrane and represent the final stabilization of Río de la Plata Craton. A reconnaissance study of petro- and magnetic fabrics based on microscopic observations, anisotropy of magnetic susceptibility and anhysteretic remanent magnetization, was carried out on 41 sites from 14 intrusive bodies, in order to obtain preliminary information on kinematics of their emplacement, degree of deformation, and regional stress regime during this magmatic event. The magnetic fabrics coupled with the microstructural analysis are interpreted as generally reflecting magma kinematics near solidus temperature, although few cases of tectonically modified fabrics at local levels have been interpreted. Field evidence and magnetic fabrics in most plutons show subvertical to high angle E-W to NE-SW trending foliations and subvertical lineations. These data suggest that plutons were probably intruded under a regional extensional to transtensional regime, which controlled the magma ascent and distribution of the intrusions. Lack of metamorphism and low to null deformation shown by the study plutons suggest a late-orogenic character for this magmatism, which has been associated with crustal stabilization after accretionary processes that led to the formation of Río de la Plata Craton in the Orosirian.
\end{abstract}

KEYWORDS: Piedra Alta terrane; Río de la Plata craton; anisotropy of magnetic susceptibility.

\section{INTRODUCTION}

The anisotropy of magnetic susceptibility (AMS) is a technique that has been widely applied to infer the rock petrofabric from the measurement of the magnetic susceptibility ellipsoid (e.g., Tarling and Hrouda 1993, De Saint-Blanquat et al.2001, Martín-Hernández et al. 2004, Raposo et al. 2012, Mondal et al. 2018). Its rapidity and simplicity have transformed this technique into a very valuable tool to study the internal structure, and therefore the emplacement kinematics of plutonic bodies in virtually all tectonic environments (e.g., Bouchez et al. 1992, López de Luchi et al. 2010, Schöpa et al. 2015, among others). The AMS has proved to be very useful on numerous occasions to determine the degree and spatial distribution of deformation in rocks with low to moderate tectonic disturbance (e.g., Rochette et al. 1992, Borradaile and Henry 1997, Bolle et al.2018; among others). The AMS ellipsoid is defined by the maximum $\left(\mathrm{K}_{1}\right)$, intermediate $\left(\mathrm{K}_{2}\right)$, and minimum $\left(\mathrm{K}_{3}\right)$

\footnotetext{
${ }^{1}$ Universidad de Buenos Aires - Buenos Aires, Argentina. E-mails: pablo.franceschinis2@gmail.com, rapalini@gl.fcen.uba.ar, candusky@gmail.com,fnmilanese@gl.fcen.uba.ar

${ }^{2}$ Consejo Nacional de Investigaciones Científicas y Técnicas Buenos Aires, Argentina.

${ }^{3}$ Universidad de la República - Montevideo, Uruguay.

E-mail: leda@fcien.edu.uy

${ }^{*}$ Corresponding author.
}

main axes (Tarling and Hrouda 1993). The relations between these axes provide information about the anisotropy magnitude and the ellipsoid shape (Jelinek 1981), which, under certain conditions, may reflect the petrofabric of the rock under investigation. However, interpretation of AMS results is, in many cases, ambiguous due to the varied minerals that contribute to the magnetic susceptibility of each rock. When well-constrained by microscopic observations and different kinds of mineral identification methods, AMS may result in a powerful tool for deciphering the emplacement kinematics of plutonic bodies and their tectonic framework (Fig. 1).

During the late Early to Middle Paleoproterozoic (ca. 2.2-2.0 Ga), a major crustal forming and stabilization event took place in Río de la Plata Craton (Sánchez Bettucci et al. 2010, Oyhantçabal et al. 2011; and references therein). This event has been well known since several decades as the “TransAmazonian” cycle (Almeida et al. 1973). It also affected other cratons, such as Congo-São Francisco (Alkmim and Marshak 1998, Toteu et al. 2001, Aguilar et al. 2017, De Waele et al. 2008) and Guyana (or proto-Amazonia, Tassinari and Macambira 1999, Delor et al. 2003, McReath and Lins Faraco 2006). In Piedra Alta terrane (Figs. 1A and 1B), which constitutes the "core" of Río de la Plata Craton, this process is recorded by the presence of large granitic-gneissic areas separated through supracrustal metamorphic belts (rhyolites, micaschists, basalts, turbidites, iron formations, among others) assigned to intra-oceanic or back-arc environments (San José, Florida and Arroyo Grande belts, Sánchez Bettucci et al. 2010). Dominant Sm-Nd 
and Lu-Hf model ages for Piedra Alta terrane (2.5-2.1 Ga) strongly suggest major crustal formation processes with little to negligible recycling of older crusts (Oyhantçabal et al. 2011, Oriolo et al. 2016). Granitic-gneissic terranes are interpreted as complexes that record juvenile products of subduction-related magmatism (Preciozzi and Bourne 1992, Schipilov et al. 1998). By around 2.0 Ga, Río de la Plata Craton was probably already a tectonically stable crustal block (Peel and Preciozzi 2006), composed by Piedra Alta terrane and Tandilia System (see Oyhantçabal et al. 2011, Cingolani 2011). Nico Pérez (Preciozzi et al. 1979) and Cuchilla Dionisio terranes in Eastern Uruguay (Rapela et al. 2011, Oriolo et al. 2016, among others) were accreted much later, during Neoproterozoic times. Crustal stabilization of Piedra Alta terrane is recorded by the intrusion of Paleoproterozoic magmatic bodies scarcely and only localized deformed. They constitute numerous small to medium-sized intrusions, dominantly but not exclusively, of granitic to granodioritic composition (see Rapalini et al.2015). Getting information on the petrofabric of these bodies may give some clues regarding the mechanisms of magma intrusion in an early Paleoproterozoic crust in the cratonization process, as well as in the general stress regime that affected them. Hence, we may contribute to a better understanding of the tectonic processes that were involved in the final formation stages of a small continent: the Paleoproterozoic Río de la Plata Craton.

Rapalini et al. (2015) presented the first magnetic fabric results on six of such igneous bodies of Piedra Alta terrane. To complement that study and obtain a more representative picture of this major tectono-magmatic process, we carried out a magnetic fabric study by means of measuring the AMS on the selected sites of 14 other intrusions (Fig. 1B). Our analysis was accompanied by microscopic observations

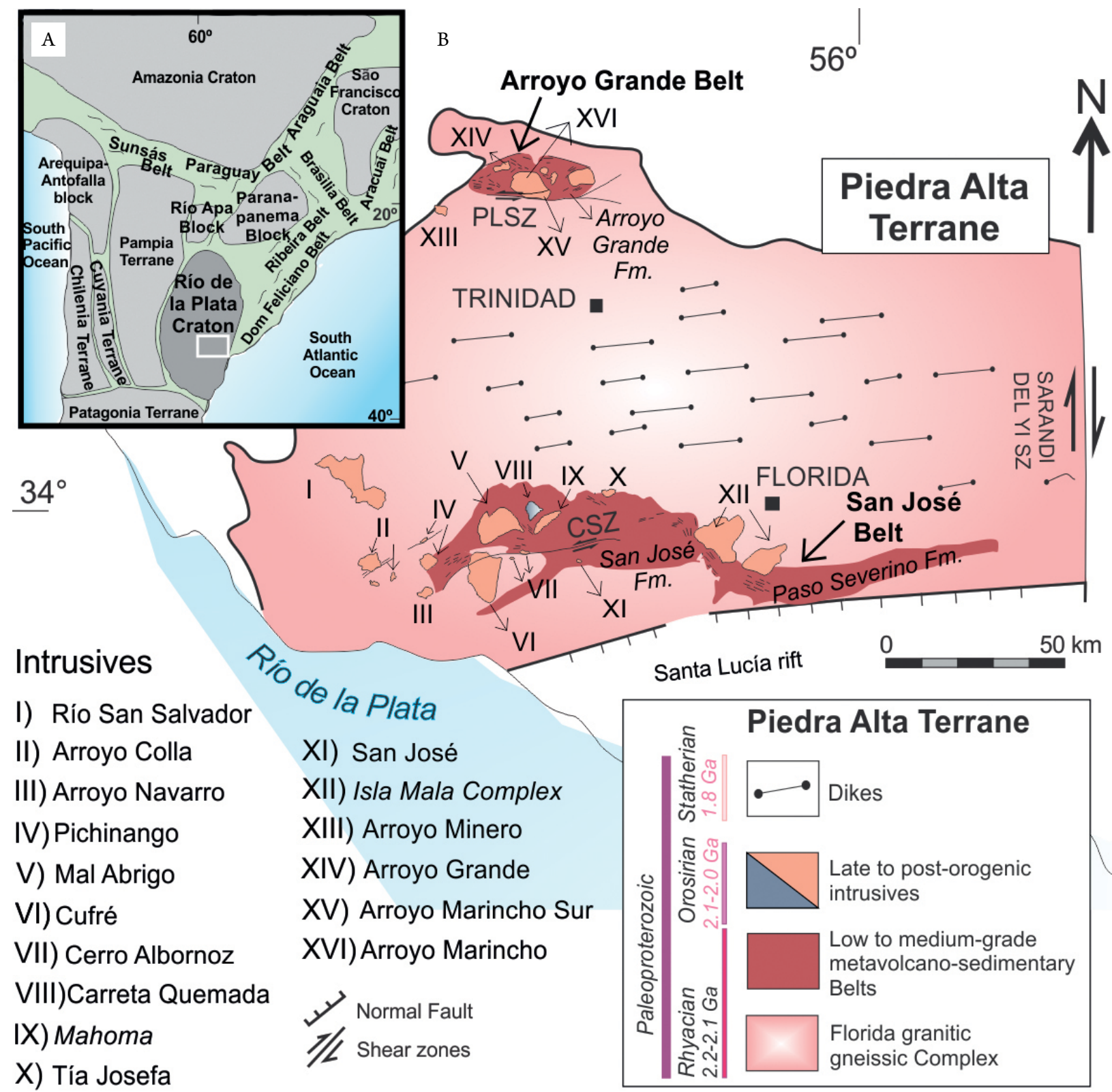

PLSZ: Paso de Lugo Shear Zone; CSZ: Cufré Shear Zone.

Figure 1. (A) Location of Río de la Plata craton and its relationship with other South American terranes and cratons. White box indicates the location of Piedra Alta terrane within Río de La Plata Craton. (B) Intrusives studied in this paper. In italics, the intrusives previously studied by Rapalini et al. (2015). Modified from Sánchez Bettucci et al. (2010), Rapalini et al. (2015) and Franceschinis et al. (2016). 
and rock-magnetic experiments in order to characterize their microstructures and to determine the main mineral phases responsible for the magnetic fabrics.

This is taken as a reconnaissance study, considering that no systematic sampling with sufficient density was carried out at each pluton. However, the consistent results obtained in most bodies strongly suggest a general regional pattern.

\section{GEOLOGICAL SETTING}

\section{Piedra Alta terrane}

Bossi et al. (1993) originally defined three outcropping metamorphic belts in the South-central part of Piedra Alta terrane. Oyhantçabal et al. (2003) reduced their number to two: Arroyo Grande and San José Belts (Fig. 1B). Both greenstone belts show an E-W trend. The former is a greenschist facies volcano-sedimentary succession represented by Arroyo Grande Formation (Oyhantçabal et al. 2011). This volcano-sedimentary sequence consists of quartzite, metapelites, metasandstones, rare meta-conglomerates, and meta-basalts and metandesites (Sánchez Bettucci et al. 2010, Oyhantçabal et al. 2011). Arroyo Grande belt is intruded by much less to virtually undeformed granitoids represented by the ca. $2.10 \mathrm{Ga}$ Marincho Complex (Rapalini et al.2015 and references therein) and is in tectonic contact with Florida granite-gneissic belt to the South by the Paso Lugo shear zone (PLSZ). This has been considered of Paleoproterozoic age, and a strike-slip sinistral behavior has been proposed (Preciozzi 1993).

San José Belt is represented by San José, Paso Severino and Montevideo formations (Fig. 1B). San José Formation consists of meta-volcanic rocks, both acidic and basic, and a metasedimentary succession. The Paso Severino formation consists of rhyolites, basalts, metapelites, carbonates, and banded iron levels. San José belt is affected by Cufré Shear Zone (CSZ) of possible Paleoproterozoic age, which is of an approximate E-W orientation and has strike-slip sinistral behavior. It also presents a series of intrusive bodies ranging from granites to gabbros of around 2.10 and $2.05 \mathrm{Ga}$ that have been classified as late- to post-orogenic (Peel and Preciozzi 2006, Hartmann et al. 2008, Oyhantçabal et al.2018). Several of these bodies were studied in this paper (Figs. 1 and 2). To the South of Santa Lucia rift, the Montevideo Formation is exposed, consisting in amphibolites, micacites and gneisses (Sánchez Bettucci et al. 2010, Oyhantçabal et al. 2011). Metamorphic grade is higher than in the North and reaches amphibolite facies. The Montevideo formation is affected by Mosquitos Shear Zone (MSZ), which has been dated as early to middle Orosirian (1909 \pm 23 and $2049 \pm 25 \mathrm{Ma}$ ) with K-Ar ages of muscovite grains (Oyhantçabal et al. 2006). This fault zone also shows an approximate E-W orientation and a strike-slip sinistral behavior. It is intruded by Paleoproterozoic postorogenic granites, such as Soca and Empalme Olmos. U-Pb (SHRIMP) zircon dating of Soca Granite (2056 $\pm 6 \mathrm{Ma}$; Santos et al. 2003) suggests that the
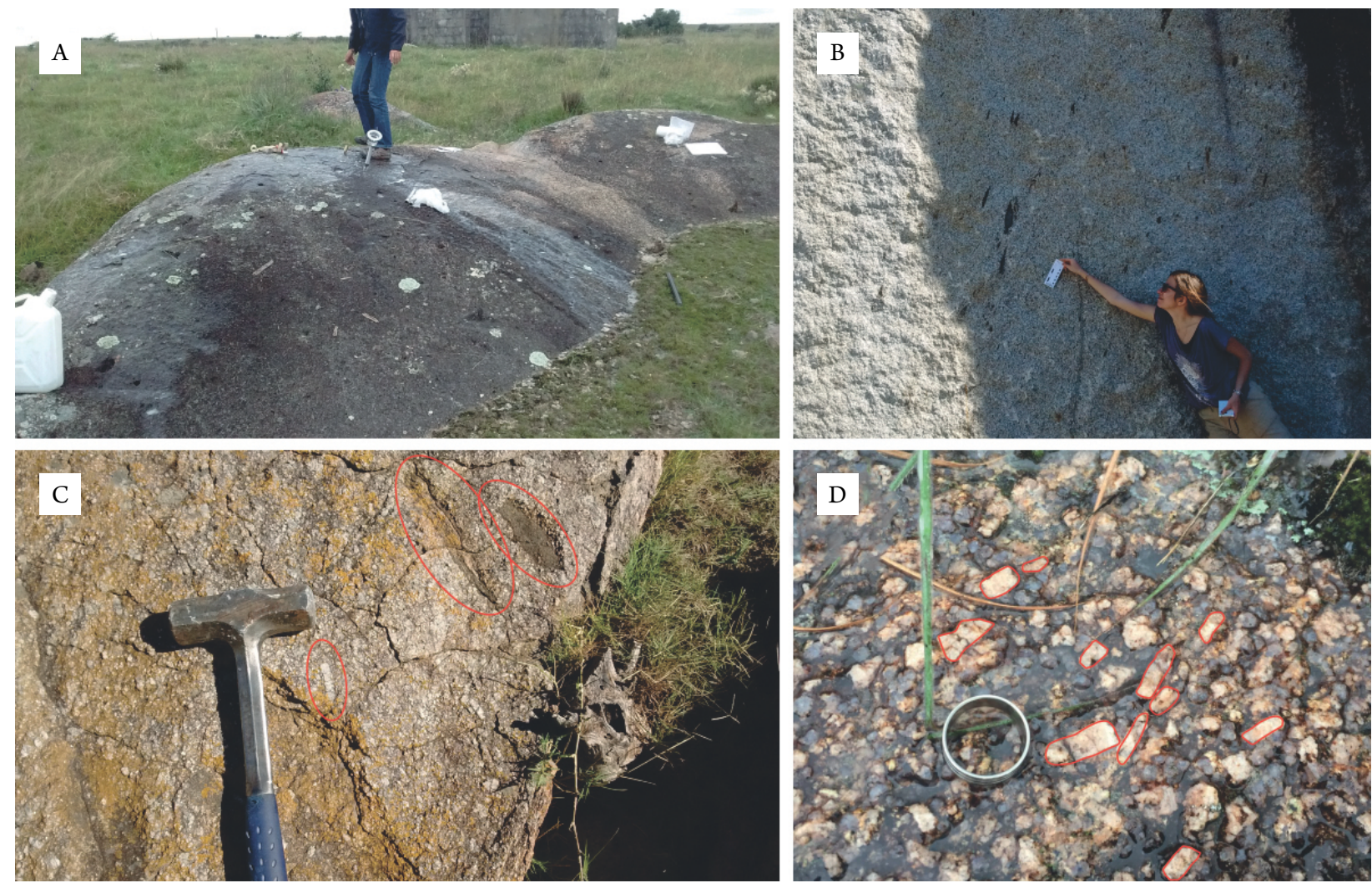

Source: modified from Franceschinis et al. (2019).

Figure 2. Field exposures of the studied rocks. (A) Cufré granite (C6 site). Representative example of outcrops in Piedra Alta terrane. They are isolated and the contact with the host rock is not easily seen. (B) Detailed texture of Cufré Granite (C9 site). Note the subvertical disposition of the enclaves in front of the quarry. (C) E-W arrangement of euhedral feldspar crystals and enclaves in the same direction (CU6 site). (d) Magmatic lineament of K-feldspar megacrysts in Arroyo Minero Granite (AM2 site). 
activity of this shear zone was approximately coeval with the emplacement of at least some of these granitic bodies.

\section{Paleoproterozoic late to post-orogenic intrusives}

All intrusive bodies studied in this paper are emplaced in or close to the Arroyo Grande and San José belts (Fig. 1B). They consist mainly of granitoids with subordinated gabbros. The age of these rocks can be bracketed somewhat between 2050 and $2100 \mathrm{Ma}$, according to precise $\mathrm{U}-\mathrm{Pb}$ (zircon) dating on the Isla Mala Suite $(2065 \pm 9 \mathrm{Ma}$ and $2074 \pm 6 \mathrm{Ma}$ for the granites, Hartmann et al. 2000; $2080 \pm 5$ Ma for the Rospide Gabbro, Hartmann et al. 2008) and the Cufré Granite (2053 $\pm 14 \mathrm{Ma}$, Peel and Preciozzi 2006; 2086 $\pm 4 \mathrm{Ma}$, Basei et al. 2016). Geochemical and isotopic studies by Preciozzi (1993), Preciozzi and Bourne (1992) and Oyhantçabal et al. (1998, 2011) determined that most of these plutons are calc-alkaline with medium to high K content. However, the A-type rapakivi Soca Granite (Santos et al.2003), exposed in the Montevideo Belt, presents a metaluminous or slightly peraluminous composition and a shoshonitic character (A2- type or post-collisional, Eby 1992).

\section{Sampling and methodology}

A magnetofabric study was carried out on 381 independently oriented cores ( 556 specimens) collected at 41 sites in 14 Paleoproterozoic intrusions, which are located in or close to San José and Arroyo Grande belts in Piedra Alta terrane (Fig. 1B). This sampling complemented a preliminary study conducted by Rapalini et al. (2015) on other six bodies (Fig. 1B). Most bodies are exposed as isolated natural outcrops or in quarries (Fig. 2). Contacts with the encasing lithologies are covered in all cases. Outcrops show slight to lack of weathering or alteration indications. Macroscopic foliation is either absent or subtle in most outcrops. However, in restricted areas, well-defined foliations were measured in order to compare them with magnetic fabric results. Sampling followed regional mapping (Preciozzi et al. 1985) that does not show a very precise definition of each body's boundaries. We generally sampled nine or ten independently oriented cores at each site, covering from a few to 100 square meters of areal extension in order to obtain representative results at a local level. The distance between sites within the same body was in the order of hundreds of meters to a few kilometers. Sampling in all plutons was conditioned by quality and accessibility of outcrops and by the fact it was performed originally for a paleomagnetic study (Franceschinis et al. 2019).

Therefore, coverage of sampling is not homogeneous, many areas of each body have remained unsampled and in many cases sampling was carried out in too few sites for a robust characterization of the magnetic fabric of each individual pluton. Cores were taken with a portable drill and, subsequently, oriented by sun and magnetic compasses and inclinometer. The difference between both compasses remained generally constant within two degrees. Cores were sliced into one to three specimens of a standard size of $2.54 \mathrm{~cm}$ in diameter and $2.2 \mathrm{~cm}$ high. Measurements of AMS and thermomagnetic curves
(Kversus $\mathrm{T}$ ) were performed with a MKF1-A susceptibilimeter (AGICO Inc) coupled with CS-L and CS3 devices. K versus $\mathrm{H}$ curves were made with the same instrument. Acquisition of isothermal remanence curves (IRM) were done with an IM-10-30 pulse magnetizer (ASC Scientific). A TD-48 ASC single chamber furnace was used for thermal demagnetization of the three axes IRM (Lowrie method, Lowrie 1990) on representative specimens. Anisotropy of anhysteretic remanence (AARM) studies were performed in the selected sites from the Cufré Granite (C2, C3), Carreta Quemada Gabbro (C8), Pichinango Granite (C18), Arroyo Minero Granite (AM2), and Arroyo Marincho Granite (GM4) with a JR6 spinner magnetometer (AGICO Inc) and a LD-A magnetizer (AGICO Inc). Petrographic thin sections representative of the intrusive bodies were studied.

\section{Anisotropy of magnetic susceptibility study}

Magnetic fabrics were well defined in almost all the analyzed sites (Figs. 3 to 6, Tab. 1). A brief description of the magnetic fabrics of each pluton is as follows.

\section{San José belt}

\section{Cufré Granite}

The Cufré granite is exposed around Cufré town, intruding the San José metamorphic belt (Fig. 1B). The body has an area of $\sim 103 \mathrm{~km}^{2}$. A coarse grain size is characteristic of this pluton with abundant quartz. Ten sites were sampled $(\mathrm{C} 1, \mathrm{C} 2$, C3, C4, C5, CU6, CU7, CU8, CU9, and CU10), from which a total of 120 independently oriented specimens were collected. All sites were located in the Northern half of the pluton with highly variable distances between sites, from $100 \mathrm{~m}$ to several $\mathrm{km}$. Macroscopic foliations were observed at some sites determined by orientation of flattened mafic enclaves (Fig. 2B) and up to $3 \mathrm{~cm}$-long feldspar crystals (Fig. 2C). Foliation, as observed in the field, is subvertical and its trend varies from N-S (C3, C4) to NNE (CU9) and E-W (CU5, CU6, CU8). Magnetic susceptibility values are between $2.6 \times 10^{-5}$ and 2.95 $\times 10^{-4}[\mathrm{SI}]$. Only some igneous mafic microgranular enclaves reached higher values of up to $5 \times 10^{-4}[\mathrm{SI}]$ (see Fig. 3A). Anisotropy degree is generally low to moderate $(\mathrm{Pj}<1.09)$ at a sample level, but it is always under $5 \%$ for the mean site AMS ellipsoid. Shape parameter (T, Jelinek 1978) shows oblate, prolate, and neutral AMS ellipsoids (Tab. 1, Fig. 3A) for different sites. $\mathrm{K}_{1}$ axes are very well clustered around the vertical direction, except for the $\mathrm{C} 3$ site, in which it shows a sub-horizontal NE trend. Dominant subvertical lineations are consistent with the observation of subvertical elongated enclaves in some sites (Fig. 2B). They strongly suggest a magnetic fabric of magmatic origin. The discordant $\mathrm{K}_{1}$ direction on $\mathrm{C} 3$ site is possibly related to local effects associated with its location close to the Northern margin of the Cufré pluton or its vicinity to the neighboring E-W Cufré shear zone (Fig. 1B). In any case, a very coherent pattern of $\mathrm{NE}$ trending subvertical magnetic foliations with dominant subvertical lineations is evident from most of the sampling sites (Fig. 3A). 

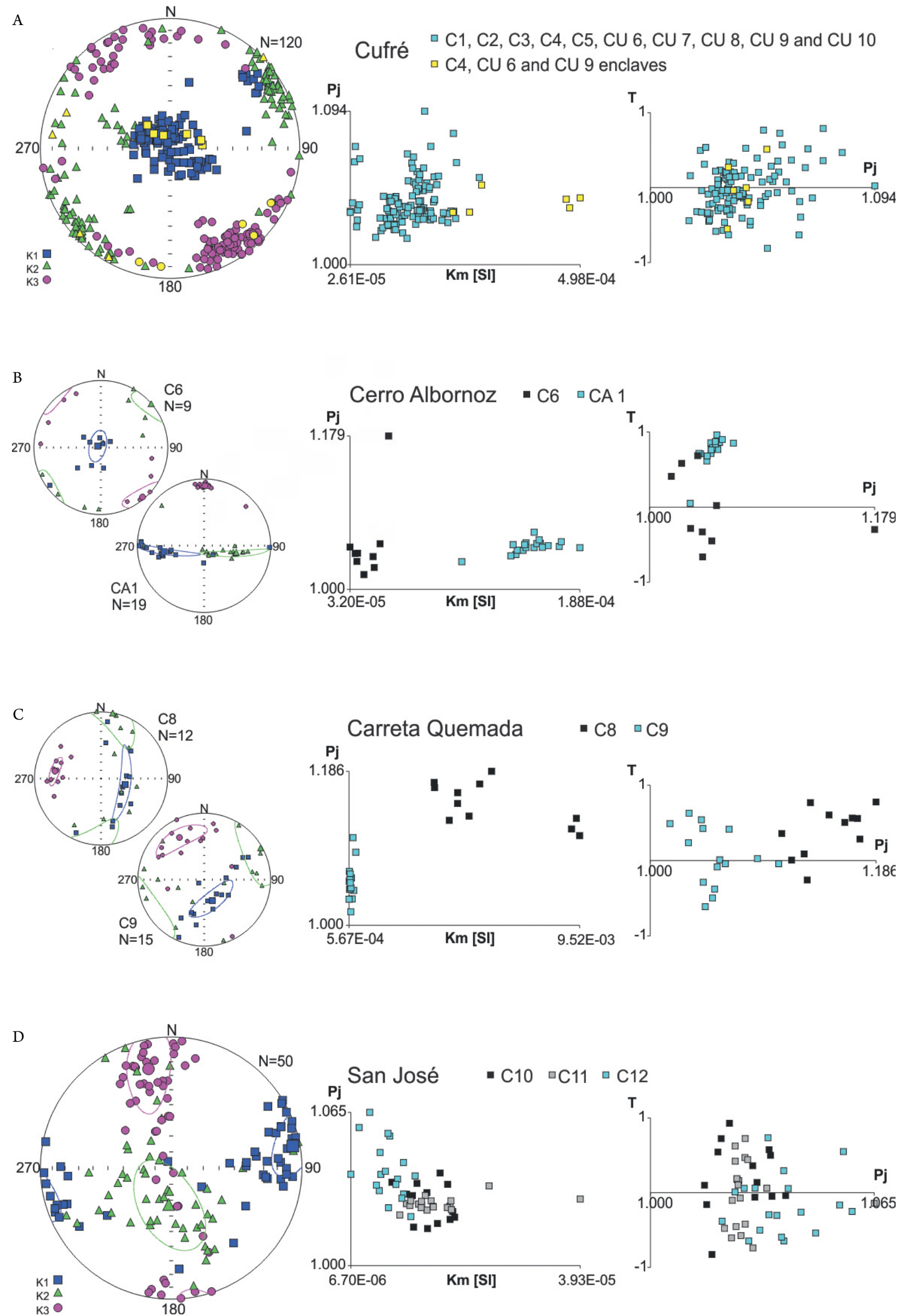

Figure 3. Stereographic projections for the main axes of the Anisotropy of Magnetic Susceptibility (AMS) ellipsoid $\left(\mathrm{K}_{1}, \mathrm{~K}_{2}\right.$, and $\left.\mathrm{K}_{3}\right)$ of Cufré, Cerro Albornoz, Carreta Quemada Complex and San José intrusives and their respective diagrams of $\mathrm{Pj}$ versus $\mathrm{Km}$ and $\mathrm{T}$ versus $\mathrm{Pj}$. (A) $\mathrm{C} 1$, C2, C4, C5, CU6, CU7, CU8, CU9 and CU10 sites from Cufré Granite. (B) Idem for sites sampled in Cerro Albornoz granite. (C) Idem for sites sampled in Carreta Quemada Complex. (D) Idem for sites sampled in San José Granite. 


\section{Cerro Albornoz Granite}

This is a small body $\left(\sim 4 \mathrm{~km}^{2}\right)$ of a coarse-grained biotite-muscovite milonitic granite located towards the East of the much larger Cufré Granite. It is represented by two main outcrops (Fig. 1B), in which two sites were sampled (C6 and CA1). A total of 28 independently oriented specimens were collected from this pluton. In CA1 site, discrete E-W bands of around $50 \mathrm{~cm}$ wide were observed and showed evidence of fragile deformation. C6 site is devoid of macroscopic deformation evidence. Bulk susceptibility values are between $3.2 \times 10^{-5}$ and $1.88 \times 10^{-4}[\mathrm{SI}]$. Site mean AMS ellipsoids show anisotropy degrees around $4 \%$. CA1 shows a very well-defined oblate fabric $(\mathrm{T}=0.863)$, while $\mathrm{C} 6$ shows neutral ellipsoidal shapes. In all cases, magnetic foliation planes are subvertical trending E-W (Fig. 3B). Lineations are subvertical on C6 site, while of low angle to sub-horizontal and trending E-W on the CA1 site. As in the case of $\mathrm{C} 3$ site (Cufré Granite), the discrepant lineation correlates with proximity to the Cufré shear zone (Fig. 1B).

\section{Carreta Quemada Complex}

Two sites were sampled (C8 and C9, $\mathrm{n}=26$ specimens) on this complex. The Carreta Quemada Complex $\left(33 \mathrm{~km}^{2}\right)$ consists of a basic intrusive (site $\mathrm{C} 8$ ) and a granitic body (site C9). C8 was sampled in a quarry, in which the rocks are unaltered, with no deformation evidence. In thin section, C9 site shows no deformation evidence after crystallization. The distance between sites is $550 \mathrm{~m}$. Bulk susceptibility values differ significantly on both sites. C8 shows values between $3.9 \times 10^{-3}$ and $9.5 \times 10^{-3}[\mathrm{SI}]$, while $\mathrm{C} 9$ presents significantly lower values between $5.7 \times 10^{-4}$ and $8.3 \times 10^{-4}[\mathrm{SI}]$. While anisotropy degree
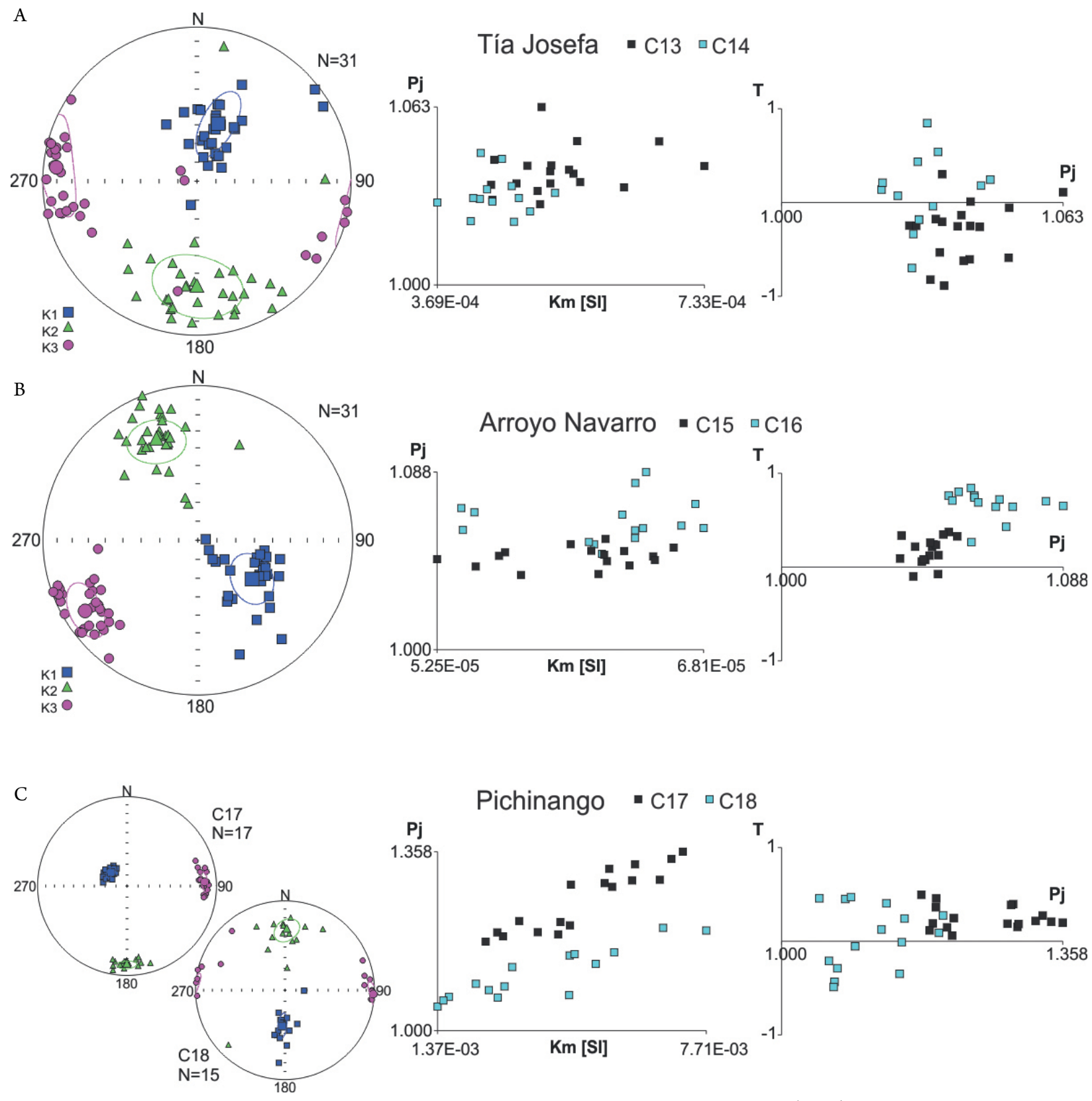

Figure 4. Stereographic projections for the main axes of the Anisotropy of Magnetic Susceptibility (AMS) ellipsoid of Tía Josefa, Arroyo Navarro and Pichinango intrusives and their respective diagrams $\mathrm{Pj}$ versus $\mathrm{Km}$ and $\mathrm{T}$ versus $\mathrm{Pj}$. (A) Stereographic projection and diagrams of the sampling sites of Tía Josefa Granite. (B) Idem for sites sampled in the Arroyo Navarro Granite. (C) Idem for sites sampled in Pichinango Granite. 
in C9 barely exceeds 6\% (mean $\mathrm{Pj}=1.036$, Tab. 1) with an oblate to prolate ellipsoidal shape, C8 presents a higher degree of anisotropy with values between 10 and $17 \%$ at the specimen level (mean site $\mathrm{Pj}=1.123$ ) and a predominantly oblate ellipsoidal shape. Pj presents some loose correlation with K values, which suggest a magnetic fabric governed by ferromagnetic (s.l.) minerals at C8. Figure 3C illustrates the AMS directional results for this unit. A moderately well-defined high angle lineation dipping to the $\mathrm{E}$ or SE has been observed on both sites. However, high angle foliation planes differed. They are approximately N-S in C8, but NE-SW at C9 (Tab. 1, Fig. 3C).

\section{San José Leucomonzogranite}

This is a coarse-grained light-colored muscovite-bearing monzogranite, with an exposed area of $\sim 2 \mathrm{~km}^{2}$, located $4 \mathrm{~km}$ South of the Cufré Shear Zone (Fig. 1). Three sites were sampled
A

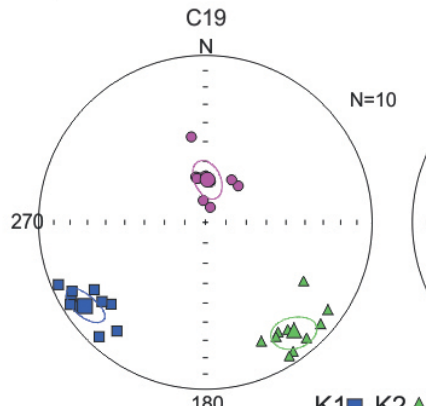

$\mathrm{K} 1 \square \mathrm{K} 2 \Delta \mathrm{K} 30$

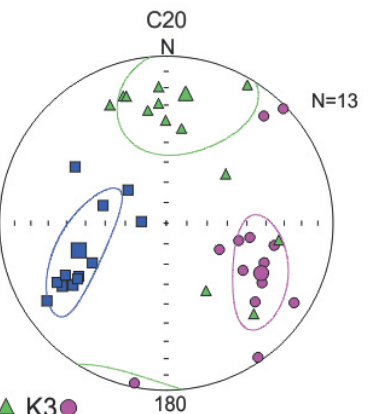

$\mathbf{T}$
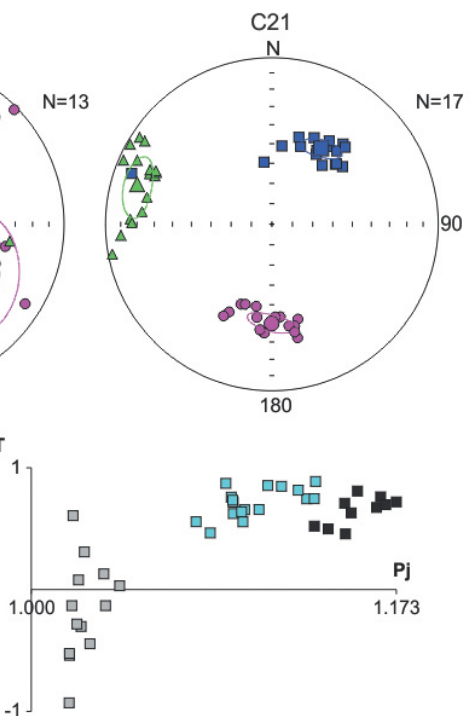

$\mathrm{B}$
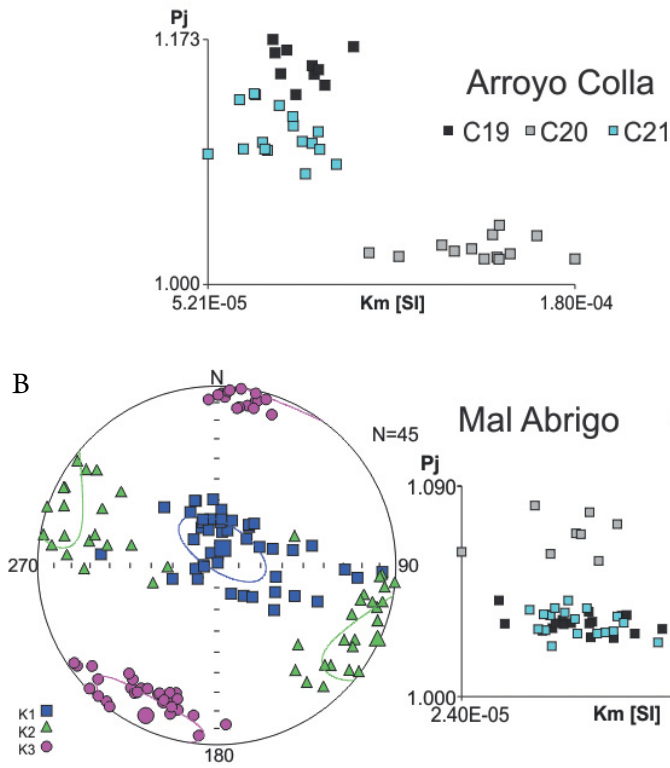

Mal Abrigo $\left.\square \mathrm{C7} \quad \begin{array}{l}-\mathrm{g} 9 \\ \square \mathrm{g} 10\end{array}\right\}$ Rapalini et al., 2015
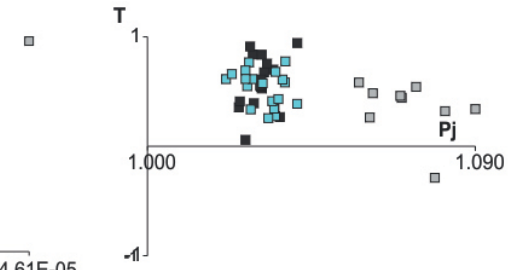

C

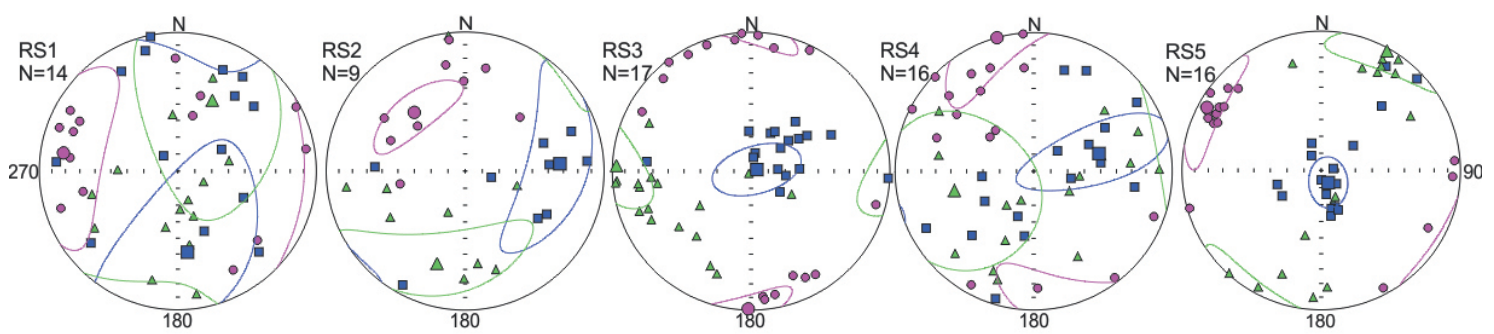

Río San Salvador -RS 1 -RS 2 -RS 3 -RS 4 घRS 5
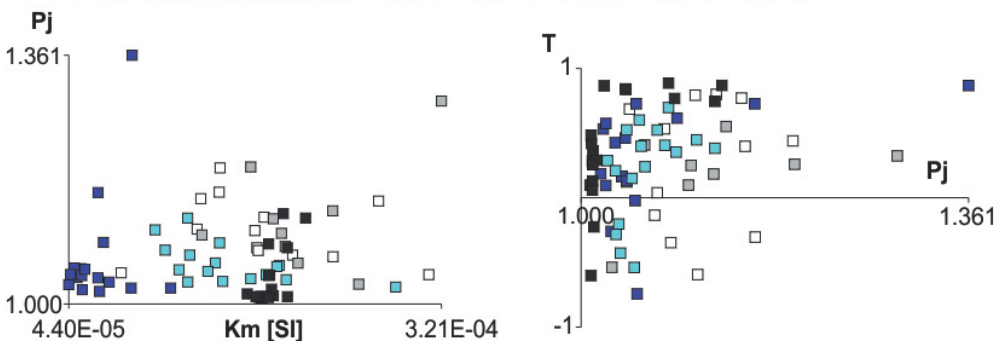

Figure 5. (A) Stereographic projections for the main axes of the Anisotropy of Magnetic Susceptibility (AMS) ellipsoid of sites C19, C20 and C21 of Arroyo Colla granite and their respective diagrams $\mathrm{Pj}$ versus $\mathrm{Km}$ and $\mathrm{T}$ versus $\mathrm{Pj}$. (B) Idem for sites sampled in Mal Abrigo Granite. (C) Idem for sites sampled in Río San Salvador Granite. 


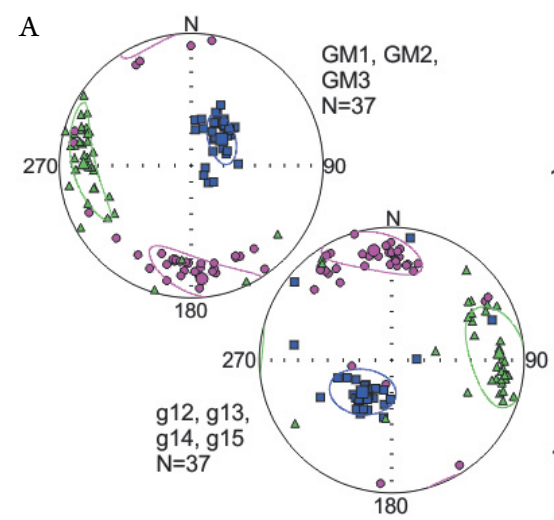

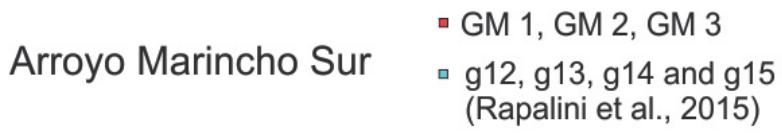
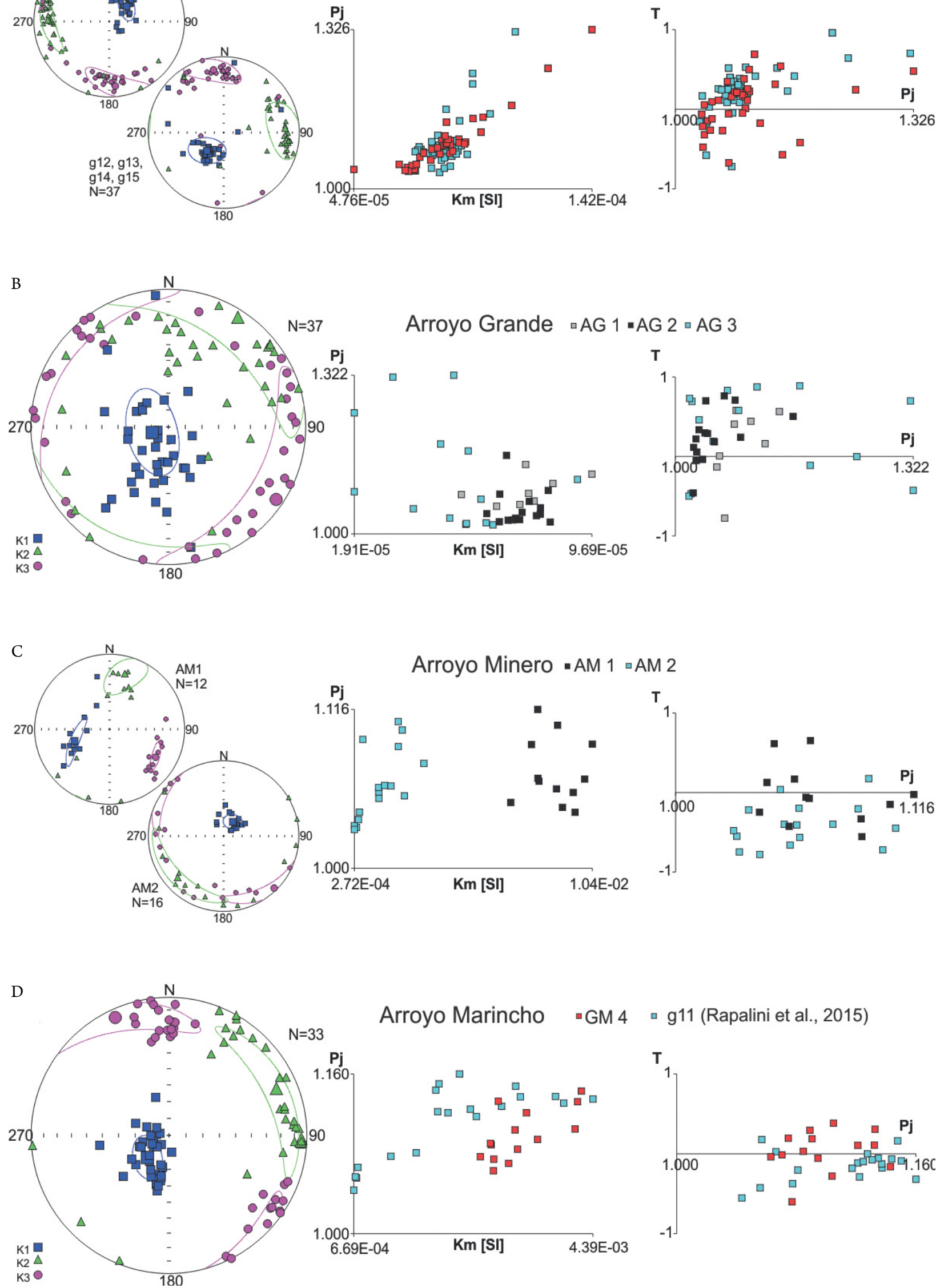

g11 (Rapalini et al., 2015)

Figure 6. Stereographic projections for the main axes of the Anisotropy of Magnetic Susceptibility (AMS) ellipsoid of Arroyo Marincho Sur, Arroyo Grande, Arroyo Minero and Arroyo Marincho intrusives and their respective diagrams Pj versus Km and T versus Pj. (A) Stereographic projection and diagrams of the sampling sites of Arroyo Marincho Sur Granite. (B) Idem for sites sampled in the Arroyo Grande Granite. (C) Idem for sites sampled in Arroyo Minero Granite. (D) Idem for the site sampled in Arroyo Marincho Tonalite. 
Table 1. Anisotropy of Magnetic Susceptibility (AMS) parameters: $\mathrm{K}_{1}, \mathrm{~K}_{2}$ and $\mathrm{K}_{3}$ correspond to the maximum, intermediate, and minimum axes of the ellipsoid, respectively. Their directions (declination/inclination) are presented with the respective $95 \%$ confidence ovals (maximum and minimum semiaxes are quoted in italics between brackets). K-mean stands for the mean site bulk susceptibility in SI units. $\mathrm{Pj}$ is the corrected anisotropy factor, and $\mathrm{T}$ is the shape parameter (Jelinek 1981). Sites in italics are those studied by Rapalini et al. (2015). Geographical extension of the intrusives is between brackets.

\begin{tabular}{|c|c|c|c|c|c|c|c|}
\hline Intrusive & Site & Kmean $(\mu \mathrm{SI})$ & $\mathbf{P j}$ & $\mathbf{T}$ & $\mathbf{K}_{1}(\mathbf{o})$ & $\mathbf{K}_{2}(\mathbf{o})$ & $\mathbf{K}_{3}(\mathbf{o})$ \\
\hline \multirow{10}{*}{$\begin{array}{l}\text { Cufré } \\
\left(103 \mathrm{~km}^{2}\right)\end{array}$} & $\mathrm{C} 1$ & 119 & 1,032 & 0.003 & $126.4 / 71.0(9.0 / 3.7)$ & $232.6 / 5.5(8.6 / 4.8)$ & $324.4 / 18.1(5.9 / 4.5)$ \\
\hline & $\mathrm{C} 2$ & 195 & 1,047 & -0.079 & $190.8 / 83.5(12.7 / 7.4)$ & $74.7 / 2.9(14.0 / 10.8)$ & $344.4 / 5.8(13.1 / 5.9)$ \\
\hline & $\mathrm{C} 3$ & 163 & 1,041 & -0.05 & $52.0 / 18.1(6.3 / 3.1)$ & $291.4 / 57.3(10.3 / 5.2)$ & $151.3 / 26.3(10.1 / 3.9)$ \\
\hline & $\mathrm{C} 4$ & 178 & 1,032 & -0.233 & $113.7 / 75.1(16.1 / 10.2)$ & $285.2 / 14.8(29.3 / 11.4)$ & $15.7 / 2.1(29.2 / 14.3)$ \\
\hline & $\mathrm{C} 5$ & 37 & 1,035 & -0.492 & $11.4 / 82.7(8.6 / 5.1)$ & $234.4 / 5.4(43.8 / 7.3)$ & $143.9 / 4.9(43.8 / 4.9)$ \\
\hline & CU6 & 194 & 1,035 & 0.175 & $2.0 / 82.0(8.3 / 6.3)$ & $219.8 / 6.4(16.6 / 6.5)$ & $129.2 / 4.9(16.6 / 8.0)$ \\
\hline & CU7 & 202 & 1,035 & 0.15 & $19.5 / 82.7(7.7 / 6.0)$ & $230.4 / 6.3(6.9 / 5.6)$ & $140.0 / 3.7(7.6 / 4.7)$ \\
\hline & CU8 & 162 & 1,032 & -0.166 & $303.2 / 72.2(5.9 / 3.3)$ & $56.6 / 7.2(8.3 / 5.0)$ & $148.7 / 16.1(8.1 / 4.0)$ \\
\hline & CU9 & 178 & 1,038 & -0.229 & $311.4 / 75.2(5.7 / 3.9)$ & $53.2 / 3.1(14.7 / 4.2)$ & $144.0 / 14.4(14.6 / 4.3)$ \\
\hline & CU10 & 107 & 1,023 & -0.207 & $312.9 / 75.7(7.3 / 2.4)$ & $58.4 / 3.9(15.4 / 6.9)$ & $149.4 / 13.7(15.3 / 2.8)$ \\
\hline \multirow{2}{*}{$\begin{array}{l}\text { Cerro Albornoz } \\
\left(4 \mathrm{~km}^{2}\right)\end{array}$} & C6 & 43 & 1,043 & -0.211 & $223.0 / 80.2(18.5 / 14.1)$ & $44.4 / 9.8(25.7 / 11.1)$ & $314.4 / 0.2(23.9 / 15.8)$ \\
\hline & CA1 & 155 & 1,048 & 0.863 & 261.8/39.1 (45.9/3.2) & $103.8 / 48.8(46.0 / 3.4)$ & $0.9 / 11.1(4.8 / 2.6)$ \\
\hline \multirow{2}{*}{$\begin{array}{l}\text { Carreta Quemada } \\
\left(33 \mathrm{~km}^{2}\right)\end{array}$} & $\mathrm{C} 8$ & 6210 & 1,133 & 0.809 & $107.5 / 58.6(38.3 / 7.2)$ & $13.3 / 2.5(38.3 / 16.8)$ & $281.8 / 31.3(17.1 / 7.0)$ \\
\hline & $\mathrm{C} 9$ & 653 & 1,038 & 0.047 & $158.8 / 62.4(33.1 / 10.8)$ & $61.5 / 3.8(35.1 / 27.1)$ & $329.6 / 27.3(30.4 / 12.6)$ \\
\hline \multirow{3}{*}{$\begin{array}{l}\text { San José } \\
\left(2 \mathrm{~km}^{2}\right)\end{array}$} & $\mathrm{C} 10$ & 18 & 1,022 & 0.547 & $86.4 / 20.3(40.4 / 9.1)$ & $230.6 / 65.5(40.5 / 13.5)$ & $351.5 / 13.1(14.0 / 9.1)$ \\
\hline & $\mathrm{C} 11$ & 20 & 1,023 & -0.35 & $85.1 / 13.7(19.6 / 14.0)$ & $212.0 / 68.0(24.6 / 18.7)$ & $350.8 / 17.0(25.5 / 10.1)$ \\
\hline & $\mathrm{C} 12$ & 12 & 1,031 & -0.526 & 73.0/0.7 (9.8/7.2) & $163.4 / 34.6(46.7 / 8.6)$ & $341.9 / 55.4(46.7 / 8.4)$ \\
\hline \multirow{2}{*}{$\begin{array}{l}\text { Tía Josefa } \\
\left(7 \mathrm{~km}^{2}\right)\end{array}$} & $\mathrm{C} 13$ & 536 & 1,029 & -0.44 & $23.0 / 53.0(23.9 / 8.3)$ & $182.8 / 35.3(31.0 / 21.0)$ & $279.8 / 9.8(30.8 / 13.4)$ \\
\hline & $\mathrm{C} 14$ & 449 & 1,028 & 0.034 & $16.8 / 65.0(9.7 / 7.0)$ & $177.6 / 23.8(14.5 / 9.0)$ & $270.9 / 7.3(14.3 / 7.5)$ \\
\hline \multirow{2}{*}{$\begin{array}{l}\text { Arroyo Navarro } \\
\left(8 \mathrm{~km}^{2}\right)\end{array}$} & $\mathrm{C} 15$ & 61 & 1,045 & 0.156 & $110.7 / 52.3(4.8 / 3.2)$ & $339.3 / 27.1(7.9 / 4.5)$ & $236.1 / 24.2(7.8 / 3.0)$ \\
\hline & $\mathrm{C} 16$ & 62 & 1,058 & 0.674 & $139.7 / 53.9(29.2 / 8.5)$ & $335.2 / 35.1(29.4 / 10.9)$ & $240.0 / 7.4(13.2 / 6.9)$ \\
\hline \multirow{2}{*}{$\begin{array}{l}\text { Pichinango } \\
\left(15 \mathrm{~km}^{2}\right)\end{array}$} & $\mathrm{C} 17$ & 4800 & 1,251 & 0.227 & $310.3 / 70.8(5.4 / 3.3)$ & $180.2 / 12.7(7.1 / 4.5)$ & $86.9 / 14.2(7.6 / 3.4)$ \\
\hline & $\mathrm{C} 18$ & 3790 & 1,104 & 0.075 & $184.3 / 56.9(12.3 / 3.8)$ & $1.7 / 33.0(13.0 / 9.0)$ & $92.4 / 1.2(10.0 / 4.0)$ \\
\hline \multirow{3}{*}{$\begin{array}{l}\text { Arroyo Colla } \\
\left(35 \mathrm{~km}^{2}\right)\end{array}$} & C19 & 85 & 1,146 & 0.629 & $235.2 / 13.1(9.7 / 6.1)$ & $141.4 / 15.9(11.3 / 7.7)$ & $2.8 / 69.1(10.1 / 6.2)$ \\
\hline & $\mathrm{C} 20$ & 147 & 1,017 & -0.328 & $252.7 / 44.3(34.8 / 11.4)$ & $8.7 / 24.2(34.3 / 26.4)$ & $117.7 / 35.9(26.8 / 14.3)$ \\
\hline & $\mathrm{C} 21$ & 77 & 1,100 & 0.686 & $33.1 / 44.8(9.9 / 4.4)$ & $285.3 / 17.1(12.4 / 8.5)$ & $180.2 / 40.2(11.4 / 4.3)$ \\
\hline \multirow{3}{*}{$\begin{array}{l}\text { Arroyo Grande } \\
\left(12 \mathrm{~km}^{2}\right)\end{array}$} & AG1 & 76 & 1,060 & 0.054 & $202.4 / 65.5(30.2 / 15.2)$ & $53.5 / 21.3(30.5 / 26.6)$ & $319.0 / 11.5(28.4 / 11.4)$ \\
\hline & AG2 & 74 & 1,034 & -0.137 & $187.4 / 66.7(18.1 / 8.5)$ & $340.9 / 21.1(49.1 / 9.6)$ & $74.6 / 9.5(49.4 / 7.5)$ \\
\hline & AG3 & 50 & 1,084 & -0.38 & $308.5 / 75.4(10.6 / 6.3)$ & $51.5 / 3.4(31.8 / 9.1)$ & $142.4 / 14.2(31.5 / 7.0)$ \\
\hline \multirow{2}{*}{$\begin{array}{l}\text { Arroyo Minero } \\
\left(7 \mathrm{~km}^{2}\right)\end{array}$} & AM1 & 8830 & 1,059 & 0.148 & $251.5 / 49.3(28.8 / 5.1)$ & $15.7 / 25.8(29.0 / 14.1)$ & $121.3 / 29.1(14.6 / 4.7)$ \\
\hline & AM2 & 1380 & 1,054 & -0.718 & $33.3 / 71.7(10.4 / 8.0)$ & $227.1 / 17.8(49.0 / 8.8)$ & $135.8 / 4.1(49.1 / 8.3)$ \\
\hline \multirow{5}{*}{$\begin{array}{l}\text { Río San Salvador } \\
\left(104 \mathrm{~km}^{2}\right)\end{array}$} & RS1 & 190 & 1,036 & 0.668 & $173.2 / 40.8(69.1 / 35.1)$ & $26.8 / 44.0(68.9 / 40.1)$ & $279.0 / 17.6(46.7 / 26.9)$ \\
\hline & RS2 & 217 & 1,067 & 0.613 & $85.6 / 32.1(56.1 / 19.9)$ & $196.5 / 29.6(56.0 / 20.1)$ & $319.1 / 43.5(29.8 / 11.9)$ \\
\hline & RS3 & 194 & 1,028 & 0.704 & $75.1 / 86.5(27.0 / 14.0)$ & $271.3 / 3.3(28.7 / 14.6)$ & $181.2 / 1.0(23.0 / 9.4)$ \\
\hline & RS4 & 66 & 1,035 & 0.557 & 74.8/49.6 (51.7/16.3) & $254.6 / 40.4(52.2 / 43.5)$ & $344.6 / 0.1(44.5 / 16.4)$ \\
\hline & RS5 & 164 & 1,045 & 0.233 & $149.8 / 81.9(15.0 / 11.3)$ & $29.4 / 4.1(28.4 / 13.0)$ & $298.9 / 7.0(28.5 / 11.4)$ \\
\hline \multirow{7}{*}{$\begin{array}{l}\text { Arroyo Marincho } \\
\text { Sur }\end{array}$} & GM1 & 86 & 1,090 & 0.147 & $42.6 / 58.0(3.6 / 1.8)$ & $285.5 / 15.9(6.0 / 3.0)$ & $187.2 / 27.0(6.1 / 1.9)$ \\
\hline & GM2 & 96 & 1,104 & -0.323 & $71.0 / 71.2(13.9 / 6.6)$ & $253.8 / 18.8(39.2 / 7.5)$ & $163.6 / 0.9(39.4 / 11.3)$ \\
\hline & GM3 & 72 & 1,050 & -0.017 & $27.1 / 62.0(10.4 / 6.5)$ & 263.6/16.4 (19.0/6.1) & $166.8 / 22.1(20.1 / 7.3)$ \\
\hline & $g 12$ & 84 & 1,086 & 0.162 & $213.9 / 61.4(7.8 / 2.0)$ & $106.4 / 9.3(24.4 / 3.9)$ & $11.7 / 26.7(24.1 / 3.0)$ \\
\hline & $g 13$ & 82 & 1,048 & 0.014 & $205.6 / 58.0(6.7 / 5.7)$ & $72.5 / 23.2(13.5 / 6.2)$ & $333.1 / 20.8(13.6 / 5.0)$ \\
\hline & g14 & 89 & 1,073 & 0.389 & $200.0 / 72.0(21.9 / 7.7)$ & $74.7 / 10.6(25.6 / 11.1)$ & $342.0 / 14.4(18.2 / 7.7)$ \\
\hline & g15 & 78 & 1,071 & 0.475 & $241.5 / 61.1(33.2 / 15.0)$ & $98.1 / 23.9(32.9 / 14.2)$ & $1.2 / 15.3(19.0 / 10.5)$ \\
\hline \multirow{2}{*}{ Arroyo Marincho } & GM4 & 3260 & 1,092 & 0.042 & $270.5 / 77.9(10.7 / 5.8)$ & $34.8 / 6.9(9.9 / 9.5)$ & $126.0 / 9.9(9.6 / 7.1)$ \\
\hline & $g 11$ & 2240 & 1,103 & -0.12 & $207.3 / 69.2(10.2 / 8.7)$ & $90.9 / 9.6(11.8 / 6.9)$ & $357.7 / 18.3(10.2 / 9.3)$ \\
\hline
\end{tabular}


Braz. J. Geol. (2020), 50(1): e20200002

Table 1. Continuation.

\begin{tabular}{lccccccc}
\hline Intrusive & Site & $\mathbf{K m e a n}(\boldsymbol{\mu} \mathbf{S I})$ & $\mathbf{P j}$ & $\mathbf{T}$ & $\mathbf{K}_{\mathbf{1}}(\mathbf{o})$ & $\mathbf{K}_{\mathbf{2}}(\mathbf{o})$ & $\mathbf{K}_{3}(\mathbf{o})$ \\
\hline & $g 3$ & 3590 & 1,063 & -0.426 & $83.4 / 57.7(21.2 / 13.3)$ & $300.5 / 26.7(26.8 / 19.2)$ & $201.8 / 16.7(25.5 / 13.3)$ \\
& $g 4$ & 20600 & 1,185 & 0.768 & $21.7 / 58.7(47.7 / 7.8)$ & $222.1 / 29.7(47.7 / 11.6)$ & $126.9 / 9.0(12.2 / 7.1)$ \\
Isla Mala & $g 5$ & 2940 & 1,120 & -0.053 & $80.7 / 40.0(9.7 / 6.6)$ & $232.1 / 46.3(19.2 / 9.3)$ & $338.0 / 14.7(19.0 / 6.4)$ \\
$\left(55 \mathrm{~km}^{2}\right)$ & $g 20$ & 283 & 1,021 & 0.363 & $221.9 / 1.1(41 / 22)$ & $131 / 29(42 / 41)$ & $314 / 61(42 / 18)$ \\
& $g 21$ & 55 & 1,009 & -0.122 & $4.8 / 46.4(52 / 23)$ & $246 / 25(44 / 37)$ & $138 / 33(51 / 41)$ \\
\hline \multirow{3}{*}{ Mahoma } & $g 6$ & 52 & 1,035 & 0.501 & $282.1 / 65.8(17.8 / 6.0)$ & $102.1 / 24.2(17.8 / 6.9)$ & $192.1 / 0.0(7.8 / 5.3)$ \\
$\left(15 \mathrm{~km}^{2}\right)$ & $g 7$ & 65 & 1,016 & 0.411 & $291.2 / 63.8(12.7 / 4.3)$ & $138.2 / 23.6(12.7 / 7.2)$ & $43.5 / 10.6(8.6 / 5.1)$ \\
& $g 8$ & 59 & 1,008 & -0.467 & $269.3 / 75.0(17.1 / 7.2)$ & $140.5 / 9.5(31.5 / 8.1)$ & $48.6 / 11.5(29.1 / 7.8)$ \\
\hline \multirow{3}{*}{$\begin{array}{l}\text { Mal Abrigo } \\
\left(71 \mathrm{~km}^{2}\right)\end{array}$} & $g 9$ & 32 & 1,029 & 0.757 & $128.7 / 78.3(38.0 / 5.2)$ & $277.0 / 10.0(38.0 / 7.0)$ & $8.0 / 6.0(7.9 / 4.3)$ \\
& $g 10$ & 32 & 1,031 & 0.54 & $24.1 / 69.5(13.3 / 3.3)$ & $293.9 / 0.1(13.3 / 8.2)$ & $203.9 / 20.5(8.2 / 3.3)$ \\
& $\mathrm{C} 7$ & 33 & 1,067 & 0.315 & $335.2 / 76.7(13.3 / 4.2)$ & $133.4 / 12.4(14.9 / 6.0)$ & $224.5 / 4.8(9.5 / 3.3)$ \\
\hline
\end{tabular}

on this body (C10, C11 and C12, $\mathrm{n}=50$ specimens), which is located from 200 to $800 \mathrm{~m}$ apart from each other. Bulk susceptibility is very low, from $6.7 \times 10^{6}$ to $2.15 \times 10^{-5}$ [SI] in all sites. Anisotropy is also very low, with a mean site $\mathrm{Pj}$ ranging from 1.022 to 1.031 and mean ellipsoidal shape varying from oblate to prolate. However, a well-defined pattern of axes distribution has been observed (Fig. 3D). $\mathrm{K}_{1}$ is sub-horizontal in an ENE-WSW direction, while the magnetic foliation is subvertical with the same trend.

\section{Tía Josefa Tonalite}

This intrusion consists of a series of small size outcrops, covering an area of about $7 \mathrm{~km}^{2}$ of a coarse grain and highly fractured tonalite exposed close to the Northern mapped boundary of San Jose metamorphic belt. Two sites were sampled on this body (C13 and C14, n = 31 specimens), located $270 \mathrm{~m}$ apart. Bulk susceptibility is moderate with specimen values between $3.7 \times 10^{-4}$ and $7.3 \times 10^{-4}[\mathrm{SI}]$. Mean site values of bulk susceptibility $\left(5.4 \times 10^{-4}\right.$ and $4.5 \times 10^{-4} \mathrm{SI}$, respectively) and anisotropy degree ( $\mathrm{Pj}, 1.029$ and 1.028$)$ were almost identical for both sites. Despite the low anisotropy degree and different ellipsoidal shape for each site (C13 predominantly prolate, $\mathrm{C} 14$ oblate to prolate), a consistent directional pattern can be observed (Fig. 4A). $\mathrm{K}_{3}$ is sub-horizontal in a WNW-ESE direction, which defines a subvertical foliation plane with NNE-SSW trend. Magnetic lineation is dipping towards the NNE with a high angle (around 60 Tab. 1).

\section{Arroyo Navarro Monzogranite}

This is a small monzogranite $\left(\sim 8 \mathrm{~km}^{2}\right)$ showing pervasive alteration in some sectors. It is located to the West of Cufré Granite (Fig. 1B). Two sites (C15 and C16; n=31) were sampled on this intrusive at $700 \mathrm{~m}$ apart. Bulk susceptibility values are low and restricted to a narrow range between $5.3 \times 10^{-5}$ and $6.8 \times 10^{-5}[\mathrm{SI}]$. Mean bulk susceptibility and anisotropy degree are similar for both sites. The latter is around $5 \%(\mathrm{Pj}=1.045$ and 1.058, respectively), and both sites present oblate ellipsoids, although $\mathrm{T}$ is much higher in the $\mathrm{C} 16$ site (Fig. 4B). Again, consistent AMS axes directions are found in specimens from both sites. Sub-horizontal $\mathrm{K}_{3}$ defines a subvertical magnetic foliation plane in a NW-SE direction. There is a high-angle magnetic lineation, pointing towards the SE.

\section{Pichinango Granite}

This pluton $\left(\sim 15 \mathrm{~km}^{2}\right)$ is exposed less than $10 \mathrm{~km}$ North from the previous one. It is represented by small outcrops of a coarse-grained and fractured granite. Two sites were sampled on this body (C17 and C18, $\mathrm{n}=32$ specimens), located $4.4 \mathrm{~km}$ apart. Bulk susceptibility values are between $1.4 \times 10^{-3}$ and $7.7 \times 10^{-3}[\mathrm{SI}]$ with very similar mean values for both sites $\left(4.8 \times 10^{-3}\right.$ and $3.8 \times 10^{-3} \mathrm{SI}$, respectively, Tab. 1$)$. They show moderate to high anisotropy degrees (mean $\mathrm{Pj}=1.104$ and 1.251). Mean ellipsoidal shape is oblate in $\mathrm{C} 17$ and neutral in $\mathrm{C} 18$. A clear correlation has been seen in both sites between the degree of anisotropy and bulk susceptibility (Fig. 4C), which is typical of fabrics governed by ferromagnetic minerals (López de Luchi et al. 2010 and references therein). However, C17 shows not only systematically higher Pj values (mean Pj 1.251 against 1.104) but also a higher slope in the Pj versus K plot, suggesting increased deformation in this site in comparison with C18. A well-defined subvertical N-S magnetic foliation is present at both sites. $\mathrm{K}_{1}$ is subvertical at $\mathrm{C} 17$ site and South high-angle dipping at $\mathrm{C} 18$ site (Fig. 4C, Tab. 1).

\section{Arroyo Colla Monzogranite}

This is a fine to medium grain size monzogranite exposed 20 to $30 \mathrm{~km}$ WSW from the Pichinango Granite. It presents two main outcrops of $\sim 20$ and $\sim 2 \mathrm{~km}^{2}$ separated by a few kilometers. Three sites (C19, C20, and C21, $\mathrm{n}=40$ specimens) were sampled on this pluton. Distances between C20 and C21 sites were approximately $500 \mathrm{~m}$ and $8.4 \mathrm{~km}$ between these sites and the C19 one. Mineralogical differences between this and the former two, as described below, suggest that both outcrops may correspond to different intrusions or at least different facies. Future detailed studies still need to confirm it. A significant amount of aplitic veins, micaceous schist xenoliths, and altered basic dykes intruding the granite were observed on C21. Some specimens were collected in an area affected by vein intrusion, while others came from an area devoid of them. No differences were found in the AMS axes directions between 
both areas, suggesting that the magnetic fabric was not affected by this episode. Bulk susceptibility values are between $5.2 \times 10^{-5}$ and $1.8 \times 10^{-4}[\mathrm{SI}]$, with mean site values of $7.7 \times 10^{-5}(\mathrm{C} 21)$, $8.5 \times 10^{-5}(\mathrm{C} 19)$, and $1.5 \times 10^{-4} \mathrm{SI}(\mathrm{C} 20)$. Variable anisotropy degrees were observed and are not related with the bulk susceptibility values (Fig. 5A, Tab. 1). C20 site, located close to the Northern mapped border of the pluton, shows the highest bulk susceptibility, a very low anisotropy degree (mean $\mathrm{Pj}=1.017$ ) and a neutral ellipsoid with a NNE-SSW foliation plane moderately dipping towards the WNW and $\mathrm{K}_{1}$ axes, clustering in a moderately plunging WSW direction. On the other hand, C19 and $\mathrm{C} 21$ sites show moderate $(\mathrm{C} 21, \mathrm{Pj}=1.100)$ to high $(\mathrm{C} 19$, $\mathrm{Pj}=1.146)$ anisotropy degrees. Ellipsoidal shapes are highly oblate (Tab. 1). No coincidence is seen, however, in the direction of the ellipsoid main axes between these sites, although the fabrics were well defined (Fig. 5A). C21, located closely to C20 (Fig. 1) shows an E-W moderately dipping to the North foliation plane and a NE trending lineation. C19, located in an isolated outcrop exposed over $8 \mathrm{~km}$ towards the South, shows a magnetic foliation plane shallowly dipping towards the South with a SW directed magnetic lineation $\left(\mathrm{K}_{1}\right)$.

\section{Mal Abrigo}

One site of this intrusive was sampled (C7), which complements two previously sampled sites ( $\mathrm{g} 9$ and g10, Rapalini et al. 2015). It has an approximate area of $71 \mathrm{~km}^{2}$, exposed $\sim 40 \mathrm{~km}$ West from San José Granite. Bulk susceptibility values are between $2.4 \times 10^{-5}$ and $4.6 \times 10^{-5}$ [SI], and mean anisotropy values are below $7 \%$. The fabric is predominantly oblate. The $\mathrm{K}_{1}$ axis is vertical, while the $\mathrm{K}_{3}$ axis is sub-horizontal, defining a vertical foliation plane oriented NW-SE (Fig. 5B).

\section{Río San Salvador Granite}

This is a relatively large body $\left(\sim 104 \mathrm{~km}^{2}\right)$ located around $20 \mathrm{~km}$ North from Arroyo Colla outcrops. Five sites were sampled (RS1, RS2, RS3, RS4, and RS5, $\mathrm{n}=72$ specimens) in the Southern half of the pluton. It consists of a pink granite with coarse to very coarse-grained texture (1-cm phenocrysts) on RS1 and RS2 sites and coarse-to-medium grain on RS4 and RS5. The granite shows a fine grain size and darker color on RS3. Mean site bulk susceptibility values range from $6.5 \times 10^{-5}$ (RS4) to $2.2 \times 10^{-4}$ [SI] on RS2 site. The fabric is predominantly oblate $(\mathrm{T}>0)$ in all sites with low anisotropy values $(\mathrm{Pj}<1.070$, Tab. 1). The magnetic fabric is loosely defined (Fig. 5C) with a subvertical foliation plane of NE-SW direction and a dominantly subvertical to high angle lineation $\left(\mathrm{K}_{1}\right)$.

\section{Arroyo Grande belt}

\section{Arroyo Marincho Sur Granite}

Specimens were collected from three sites in this granitic body (GM1, GM2, and GM3, $\mathrm{n}=37$ specimens), each at a distance between $100 \mathrm{~m}$ and $1 \mathrm{~km}$ from the nearest site. GM1 is a gray granite of fine-to-medium grain with subhedral plagioclase $(<0.4 \mathrm{~cm})$, quartz $(0.1-0.2 \mathrm{~cm})$, and laminar biotite $(0.1-0.2 \mathrm{~cm})$. GM2 shows a larger grain size (phenocrystals $>0.8 \mathrm{~cm}$ ) with a higher proportion of potassium feldspar. A well-developed macroscopic E-W mineral foliation is observed on this site, probably due to a greater amount of phyllosilicates. $200 \mathrm{~m}$ to the North, the GM3 site has a well-developed macroscopic foliation with an ENE trend and a moderate inclination towards the SSE.

The AMS study shows susceptibility values ranging from $4.76 \times 10^{-5}$ to $1.42 \times 10^{-4}$ [SI] for specimens from different sites, but with very similar mean site values: 8.5 , 9.6 and $7.2 \times 10^{-5} \mathrm{SI}$, for GM1, GM2 and GM3, respectively. On the other hand, the mean anisotropy at all sites is less than $10 \%$, and there is no dominant ellipsoidal shape. The magnetic lineation $\left(\mathrm{K}_{1}\right)$ has a high angle at all sites, with an orientation towards the NE (Fig. 6A). $\mathrm{K}_{3}$ is sub-horizontal and determines a subvertical foliation plane with E-W orientation. The magnetic fabric parameters of other sites in this pluton were presented by Rapalini et al. (2015) (see Tab. 1) and will be discussed.

\section{Arroyo Grande Granite}

Three sites were sampled on this body (AG1, AG2 and AG3, $n=37$ specimens), separated each other more than $2 \mathrm{~km}$ (exposed surface of the pluton is about $12 \mathrm{~km}^{2}$ ). It is an unequigranular granite of medium grain size $(0.3-0.5 \mathrm{~cm}$ phenocrysts) with white feldspar euhedral crystals. No macroscopic foliation was observed in the field. Sample bulk susceptibility values range from $1.91 \times 10^{-5}$ to $9.69 \times 10^{-5}[\mathrm{SI}]$, with very similar mean site values of 7.5, 7.4 and $5.0 \times 10^{-5}[\mathrm{SI}]$. Anisotropy degree is low to moderate at a site level $(\mathrm{Pj}=1.03$ to 1.08$)$, with $\mathrm{T}$ values close to zero or slightly prolate (see Tab. 1). Magnetic lineation $\left(\mathrm{K}_{1}\right)$ is of high angle to subvertical at all sites. $\mathrm{K}_{3}$ axes are sub-horizontal in the SE and NW quadrants and they determine a subvertical NE-SW trending magnetic foliation plane (Fig. 6B).

\section{Arroyo Minero Granite}

Two sites (AM1 and AM2, $\mathrm{n}=28$ ) were sampled on this small body $\left(\sim 7 \mathrm{~km}^{2}\right)$. At AM1 the pluton consists of a porphyritic granite with pink K-feldspar mega-crystals of up to $2-3 \mathrm{~cm}$ long in a mafic rich granite matrix. At AM2 the grain size is larger with subhedral K-feldspar mega-crysts $(4 \mathrm{~cm})$, in a matrix rich in quartz with minor amounts of K-feldspar, biotite and plagioclase, in decreasing order of abundance. In some sectors, agglomerates of K-feldspar mega-crysts were observed. No macroscopic mineral foliation could be determined in these sites. Bulk susceptibility values obtained in both sites are different, and the AM2 values were significantly lower (between $2.72 \times 10^{-4}$ and $3.24 \times 10^{-3}$ [SI], mean site $\left.\mathrm{K}=1.4 \times 10^{-3}[\mathrm{SI}]\right)$. AM1 bulk susceptibility sample values are between $6.95 \times 10^{-3}$ and $1.04 \times 10^{-2}[\mathrm{SI}]$, meanwhile the site mean $\mathrm{K}$ is $\left.8.80 \times 10^{-3}[\mathrm{SI}]\right)$. The mean site $\mathrm{Pj}$ values are similar (1.059 and 1.054, respectively); however, the AM1 T parameter is slightly oblate while for AM2 is predominantly prolate. The magnetic lineation axis $\mathrm{K}_{1}$ is subvertical (AM2) to moderately plunging towards the SW (AM1), while $\mathrm{K}_{3}$ is sub-horizontal and defines a subvertical foliation plane in the NE-SW direction for both sites (Fig. 6C). 


\section{Arroyo Marincho Tonalite}

The GM4 site is $6.3 \mathrm{~km} \mathrm{NW}$ of the GM3 site and corresponds to a fine grain gray granite with a much larger amount of biotite than amphibole. It has high susceptibility values (site mean of $\left.3.3 \times 10^{-3} \mathrm{SI}\right)$, which would allow a correlation with the g11 site $\left(2.24 \times 10^{-3} \mathrm{SI}\right)$ of Rapalini et al. (2015) that is located approximately $1 \mathrm{~km}$ away. The fabric is predominantly oblate $(\mathrm{T}>0)$, with some neutral or prolate specimens. The distribution of the main anisotropy axes shows the $\mathrm{K}_{1}$ axes with a high-angle westward inclination. The $\mathrm{K}_{3}$ axis is sub-horizontal and, therefore, determines a subvertical foliation plane with NE-SW orientation (Fig. 6D).

\section{Previous studies}

Six intrusive bodies were sampled for AMS by Rapalini et al. (2015). In the Arroyo Grande belt, four sites ( $\mathrm{n}=38$ specimens) were located in the Arroyo Marincho Sur granite, which was also sampled in our study, yielding a total of seven sites distributed along this body (Tab. 1). Similar results to our study had been obtained by these authors, with a sub-vertical $\mathrm{K}_{1}$ axis and one foliation plane in an approximate E-W trend (see Tab. 1). In the San José belt, three intrusives were sampled, i.e., Mal Abrigo (two sites, $\mathrm{n}=36$ ), Mahoma (three sites, $\mathrm{n}=31$ ) and Isla Mala (five sites, $\mathrm{n}=74$ ). In both Mal Abrigo and Mahoma plutons, a similar general trend was observed in the AMS ellipsoids with subvertical magnetic lineations $\left(\mathrm{K}_{1}\right)$ and sub-horizontal $\mathrm{K}_{3}$ defining subvertical WNW-ESE magnetic foliation planes. The magnetic fabric of Isla Mala pluton is more variable and, in some cases, less well defined, but it shows dominant high-angle lineations and subvertical foliations with variable directions (see Tab. 1). The bulk susceptibility values of the bodies studied by Rapalini et al. (2015) are found mainly in the paramagnetic domain, with the exception of Isla Mala pluton that presents three sites with clear influence of a ferromagnetic fraction (Tab. 1). In all cases, anisotropy degrees were found to be lower than $10 \%(\mathrm{Pj}<1.1)$. AMS data published by Rapalini et al. (2015) from the Soca and Empalme Olmos granites have not been included in our paper since those plutons intrude the Montevideo Belt, which is located to the South of our study area.

\section{Scalar parameters of magnetic susceptibility anisotropy}

Site mean values of anisotropy degree $(\mathrm{P} j)$ versus bulk susceptibility $(K)$ and shape parameter $(\mathrm{T})$ versus anisotropy degree $(\mathrm{Pj})$ are presented in Figure 7 for plutons of this study plus those reported by Rapalini et al. (2015). They show a wide range of susceptibility values of over three magnitude orders, showing paramagnetic $(\leq 500 \mu \mathrm{SI})$ to ferromagnetic $(\geq 5,000 \mu \mathrm{SI})$ character. However, most sites present values within the paramagnetic field (Tarling and Hrouda 1993). $\mathrm{Pj}$ values are generally under 1.10. Only one site shows $\mathrm{Pj}>1.20$. It corresponds to the Pichinango (C17) intrusive that shows the lowest bulk susceptibility value of all study sites. Its high $\mathrm{Pj}$ (1.270) is interpreted as an artifact due to a significant diamagnetic influence in the susceptibility values along each ellipsoid axis, which artificially magnifies the anisotropy degree calculation. A poorly defined correlation between $\mathrm{Pj}$ and $K$ is observed for most plutons (Fig. 7A). Shape parameter shows a range of values that fall in the oblate, as well as in the neutral and prolate domains (Fig. 7B). No correlation has been seen between $\mathrm{Pj}$ and $\mathrm{T}$, which is generally the case in bodies with little to negligible internal deformation (e.g., Bolle et al. 2003).
A

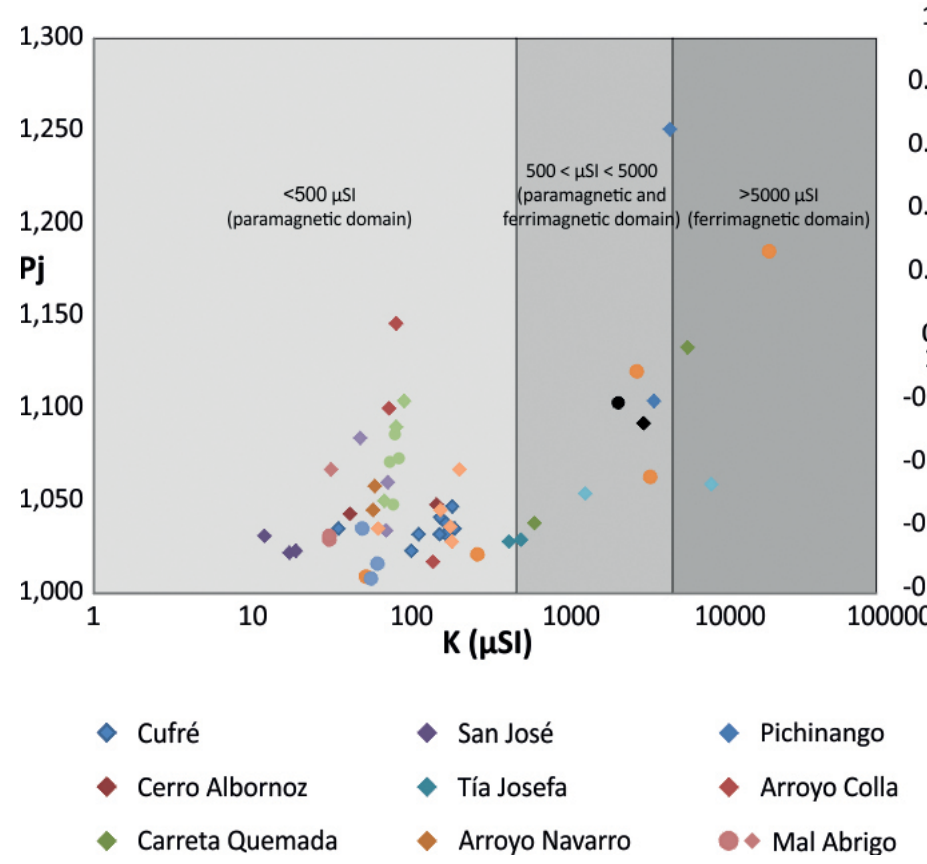

B

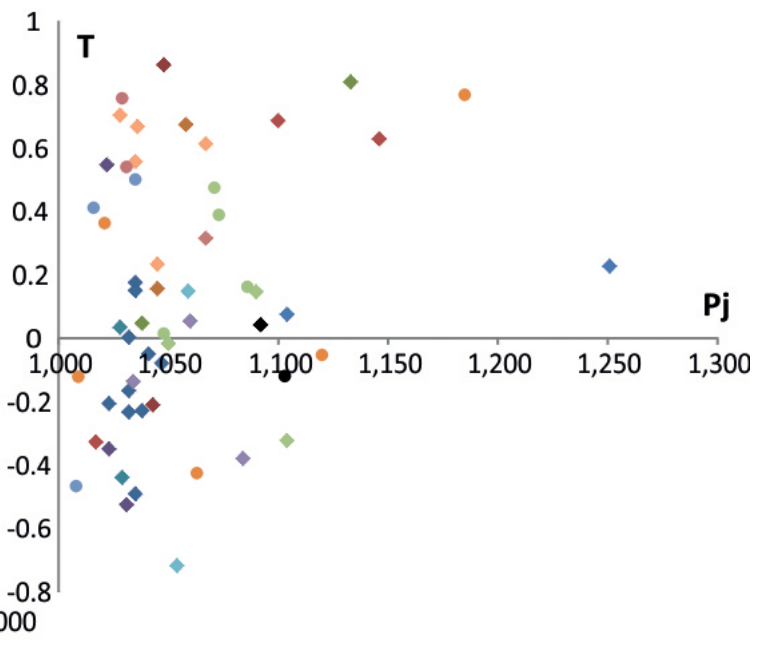

- Arroyo Marincho

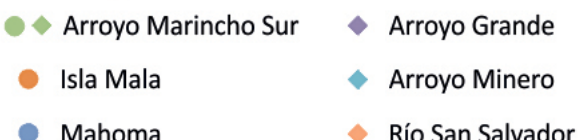

Figure 7. (A) Mean anisotropy degree ( $\mathrm{Pj}$ ) versus mean bulk susceptibility (k) for each sampling site on the intrusives of Piedra Alta terrane. Different sites are shown with different colors. (B) Jelinek (1981) shape parameter (T) versus $\mathrm{Pj}$ for each site. Diamonds are the sites studied in this work, and the circles are those studied by Rapalini et al. (2015). 


\section{Rock magnetism and remanence anisotropy}

For a better understanding of the magnetic mineralogy controlling the magnetic fabrics, several rock-magnetic studies were performed. These consisted in low and high temperature thermomagnetic (Kversus $\mathrm{T}$ ), Kversus $\mathrm{H}$ and isothermal remanent magnetization (IRM) acquisition curves plus thermal demagnetization of three IRM axes. We also performed AARM measurements on six sites from Cufré Granite (C2 and C3), Carreta Quemada Gabbro (C8), Pichinango Granite (C18), Arroyo Minero Granite (AM2), and Arroyo Marincho Granite (GM4). Representative IRM curves from the 42 studied sites are presented in Figures 8A and 8B. In general, similar magnetic behavior has been observed at different sites of the same intrusive.
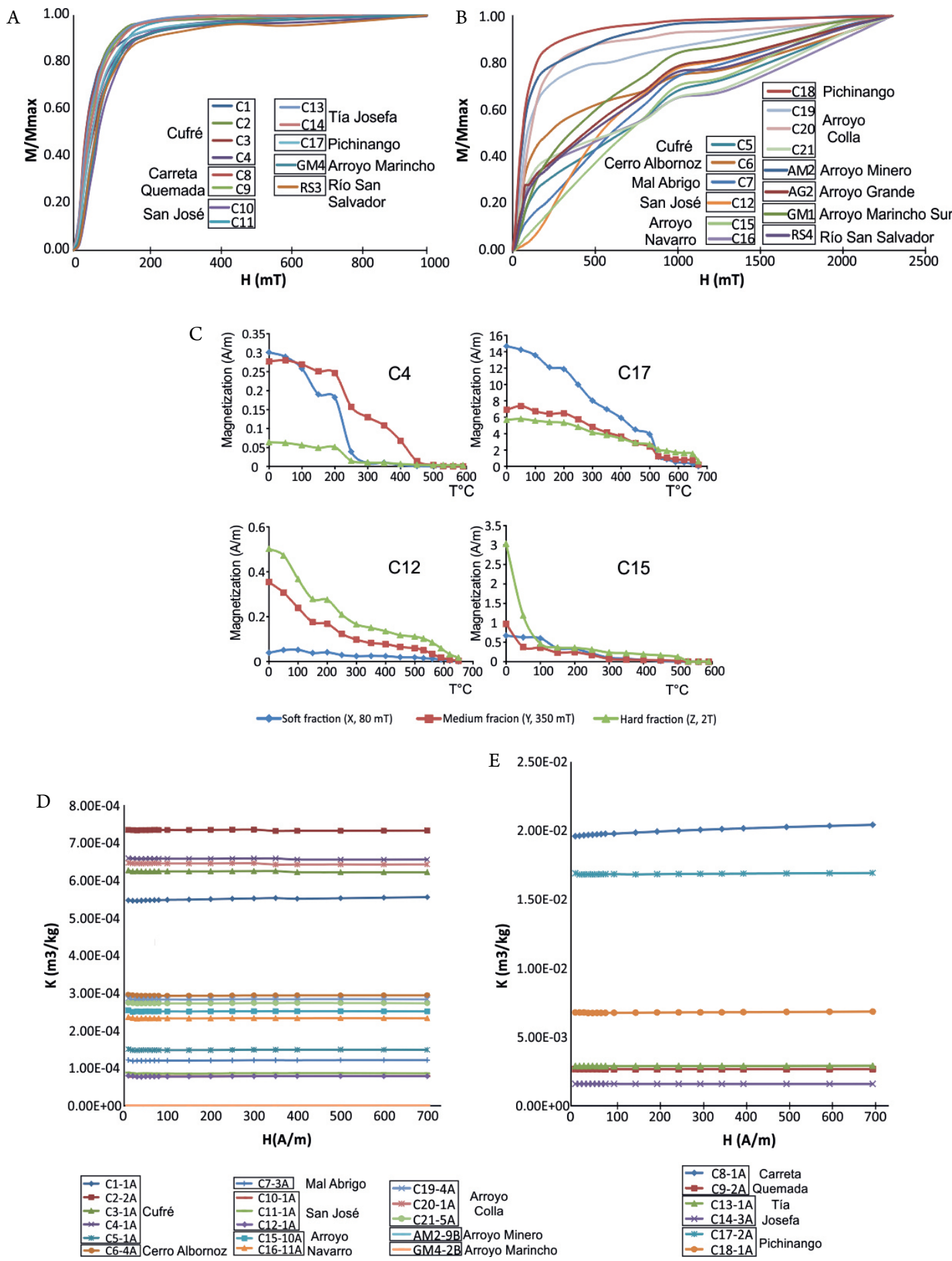

Figure 8. Isothermal remanent magnetization (IRM) acquisition curves. (A) Sites with ferrimagnetic minerals. (B) Sites with antiferromagnetic minerals. (C) Four examples of the Lowrie tests performed on the sampled sites. The fields applied on each axis are indicated. Note the significant magnetization drop in the ferrimagnetic sites ( $\mathrm{C} 4$ and $\mathrm{C} 17)$ and the typical behaviors of goetithe in the $\mathrm{C} 12$ and $\mathrm{C} 15$ sites, although in the former, a participation of hematite is also suggested. (D) $\mathrm{k}$ norm versus field $(\mathrm{H})$ curves for sites with a paramagnetic dominant fraction. Cufré Granite (C1 to C5), Cerro Albornoz Granite (C6 and C7), San José Granite (C10 to C12), Arroyo Navarro Granite (C15 and C16), Arroyo Colla Granite (C19 to C21), Arroyo Minero Granite (AM2), and Arroyo Marincho Tonalite (GM4). (E) Idem for sites with a ferrimagnetic dominant fraction. Carreta Quemada Complex (C8 and C9), Tía Josefa Tonalite (C13 and C14), and Pichinango Granite (C17 and C18). 
Plutons can therefore be subdivided into two groups according to their IRM acquisition curves, illustrated by Figures $8 \mathrm{~A}$ and $8 \mathrm{~B}$, respectively. The first group shows curves that reach saturation at fields under $400 \mathrm{mT}$ (Fig. 8A), strongly suggesting that their remanence is controlled by ferrimagnetic phases (probably Ti-magnetite). They include the Cufré (C1 to C4 sites), Carreta Quemada gabbro (C8 site) and Carreta Quemada granite (C9 site), San José (C10 and C11 sites), Tía Josefa (all sites), Pichinango (all sites), Arroyo Marincho (GM4 site), and Río San Salvador (RS3 site) intrusives. Carreta Quemada and Pichinango granitoids show susceptibility values between the paramagnetic and ferromagnetic domains, while the remaining sites belong to the paramagnetic field (see Fig. 7).

The other group (Fig. 8B), represented by Cufré (C5 site), Cerro Albornoz (both sites), San José (C12 site), Arroyo Navarro (all sites), Arroyo Colla (all sites), Arroyo Minero (AM2 site), Arroyo Grande (AG2 site), Arroyo Marincho Sur (GM1 site) and Río San Salvador (RS4 site) plutons, is characterized by saturation not reached at fields under $2 \mathrm{~T}$, with a significant contribution of antiferromagnetic phases mixed with ferrimagnetic minerals. Only in a very few cases, ferrimagnetic contributions are negligible (C15 Arroyo Navarro, C12 San José, and C7 Mal Abrigo intrusives).

In order to better determine the magnetic mineralogy responsible for the IRM acquisition pattern, representative specimens from different plutons were submitted to three IRM axis at fields of $80 \mathrm{mT}, 350 \mathrm{mT}$ and $2 \mathrm{~T}$ to discriminate the magnetic fractions with low (soft), intermediate (medium), and high (hard) coercivity. Then, specimens were submitted to stepwise thermal demagnetization in order to correlate coercivity and unblocking temperature spectra (Lowrie 1990). Representative results are illustrated in Fig. 8C. Samples C4 (Cufré Granite) and C17 (Pichinango Granite) correspond to the "ferrimagnetic" type of IRM acquisition curves (Fig. 8A); in both, the soft and medium fractions dominate. $\mathrm{C} 4$ shows a single unblocking temperature between $200-300^{\circ} \mathrm{C}$ consistent with Ti-magnetite as the only remanence carrier. $\mathrm{C} 17$ presents a dominant unblocking temperature near $530^{\circ} \mathrm{C}$ that is consistent with (Ti poor) magnetite plus a subordinate contribution of hematite as determined by the small drop in the hard fraction curve around $680^{\circ} \mathrm{C}$. Specimens C12 (San José) and C16 (Arroyo Navarro) are representative of IRM acquisition curves with significant or exclusive contribution from antiferromagnetic fractions (Fig. 8B). Consistently, hard fraction dominates the isothermal remanence. $\mathrm{C} 12$ shows a more complex pattern with a significant presence of goethite, as indicated by a major decrease in the hard and medium fraction curves up to $150^{\circ} \mathrm{C}$ plus minor contribution from hematite suggested by some remanence in the hard fraction over $600^{\circ} \mathrm{C}$. Decrease of the medium fraction curve to reach near zero close to that temperature suggests a very minor contribution of magnetite. $\mathrm{C} 15$, on the other hand, shows a well-defined unblocking temperature around $100^{\circ} \mathrm{C}$, indicating that the remanence is almost exclusively carried by goethite.

Susceptibility versus field intensity was measured (Figs. 8D and 8E). Results in Fig. 8D are consistent with susceptibility dominated by paramagnetic minerals. On the other hand, some sites presented susceptibility values of one or two orders of greater magnitude (Fig. 8E), attributed to the dominance of multidomain magnetite (Hrouda et al.2006) as a contributor to the bulk susceptibility of those plutons with high $k$ values.

Thermomagnetic curves ( $k$ versus $\mathrm{T}$ ) were performed on one sample per intrusive body (exceptions were the Cufré, Arroyo Colla, Arroyo Marincho and Río San Salvador Granites, for which two specimens from different sites were processed). Analyzed samples belong to the following sites: C2, C3, C6, C9, C10, C14, C15, C18, C19, C20, C22, AG1, AM2, GM1, GM4, RS3, and RS4. Low temperature curves were obtained by cooling a crushed sample with liquid nitrogen up to around $-190^{\circ} \mathrm{C}$ and by bulk susceptibility monitoring during heating up to room temperature. High temperature curves were performed in an inert atmosphere by continuous injection of $\mathrm{Ar}$ from ambient temperature to $680^{\circ} \mathrm{C}$ and cooling back to room temperature. C18, AM2, and GM4 samples from Pichinango, Arroyo Minero and Arroyo Marincho Granites, respectively, show a well-developed Verwey transition (Verwey 1939) of around $-155^{\circ} \mathrm{C}$ (Fig. 9A) in the low-temperature curves, which is consistent with magnetic susceptibility governed by magnetite and, therefore, the ferromagnetic fraction. Those three sites show mean $k>10^{-3} \mathrm{SI}$ (Tab. 1). All remaining samples have a typical paramagnetic decay of $k$ versus $\mathrm{T}$ consistent with bulk susceptibility values in the paramagnetic domain $\left(<5 \times 10^{-4} \mathrm{SI}\right.$, Tarling and Hrouda 1993). High-temperature curves are slightly to clearly irreversible (Figs. 9B and 9C). In most of them, a Curie temperature between 550 and $580^{\circ} \mathrm{C}$ was observed that indicates (Ti-poor) magnetite. Hopkinson peaks are observed in some cases (Fig. 9D) between 500 and $580^{\circ} \mathrm{C}$, suggesting the existence of SD magnetite in some plutons (i.e., the Pichinango and Arroyo Marincho Granites). Mineralogical changes after $400^{\circ} \mathrm{C}$ suggest formation of magnetite during heating as indicated by the cooling curve. "Tails" at temperatures higher than $580^{\circ} \mathrm{C}$ may suggest the presence of hematite, although three-axis IRM thermal demagnetization have shown that hematite, although present in some plutons, is generally not a dominant phase.

AARM measurements were conducted on C2, C3 (Cufré Granite), C8 (Carreta Quemada Gabbro), C18 (Pichinango Granite), AM2 (Arroyo Minero Granite), and GM4 (Arroyo Marincho Granite) sites (Fig. 10). Five specimens per site were submitted to anhysteretic remanence acquisition using an LDA-3A (Agico) magnetizer at alternating fields of $90 \mathrm{mT}$ $\left(\mathrm{H}_{\mathrm{ac}}\right)$ and a direct field of $50 \mu \mathrm{T}\left(\mathrm{H}_{\mathrm{dc}}\right)$. They were subsequently measured in a JR6 (Agico) spinner magnetometer following a protocol of 12 positions. Analysis was done using the AREM (AGICO) software. This study aimed to analyze the ferromagnetic fraction influence in the overall AMS pattern, particularly in those sites with moderate to high values of bulk susceptibility. Considering that SD magnetite produces an inverse AMS fabric (Potter and Stephenson 1988), consistent AMS and AARM ellipsoids permit to rule out such possibility and give extra confidence to the geologic meaning of the AMS fabric. Comparison of both ellipsoids in every site (Fig. 10) indicates that $\mathrm{K}_{3}$ axis does not change significantly between both ellipsoids, although in some cases, like in C2, $\mathrm{C} 18$ and AM2 sites, it is more poorly defined. This strongly 
suggests that the magnetic foliation determined in our study by means of AMS is not affected by inverse fabrics. Four out of six studied sites (C3, C8, C18 and AM2) show very similar orientation of both ellipsoids (AMS and AARM). Thus, inverse fabrics are not present. AARM of site C2 (Cufré Granite) is poorly defined, and no conclusions can be obtained from it.

Finally, GM4 (Arroyo Marincho) shows a permutation of $\mathrm{K}_{1}$ with $\mathrm{K}_{2}$ possibly due to the presence of an intermediate AMS fabric because of the coexistence of SD and MD magnetite grains (Ferré 2002) or the AARM showing a fabric of different origin to that of the AMS (Dunlop and Ozdemir 1997, Trindade et al. 1999, Raposo and Berquó 2008). Considering that remanence anisotropy Kmax axis is sub-horizontal and trending NE, a tectonic origin of this fabric produced by ferromagnetic grains associated with deformation along NE-SW subvertical strike-slip shear zones (i.e., Paso Lugo Shear Zone) cannot be ruled out and should be further investigated. In general, AARM shows larger dispersion and a much larger anisotropy degree (Tab. 2), but the presence of intermediate AMS fabrics can be considered the exception and not the rule.

\section{Microstructures}

Plutons were studied through microscopic observations of petrographic thin sections. This permitted to characterize the mineralogy, textures, structure, and microstructures (Fig. 11) and couple these observations with the macroscopical information.

The unit mapped by Preciozzi et al. (1985) as Cufré Granite comprises at least two different facies: a biotite-amphibole bearing porphyritic granite (C3) with magmatic to sub-magmatic
A

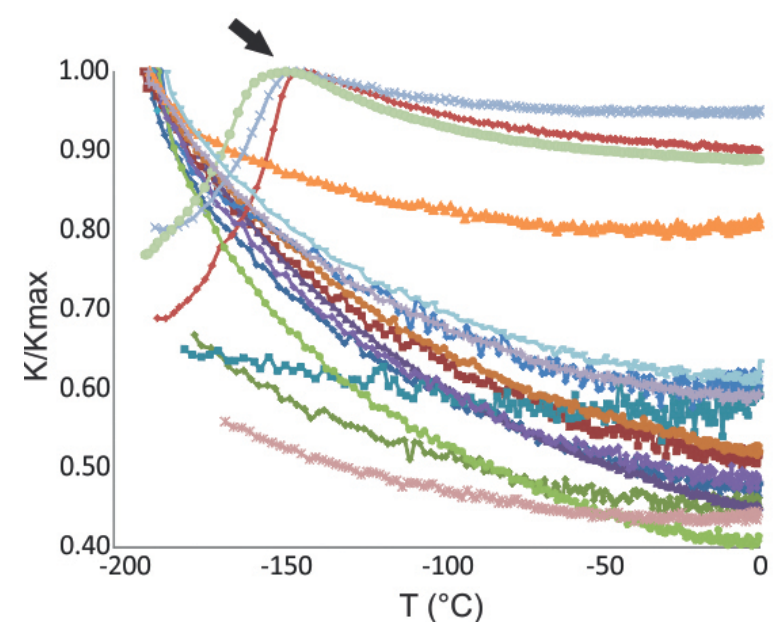

B

Kt

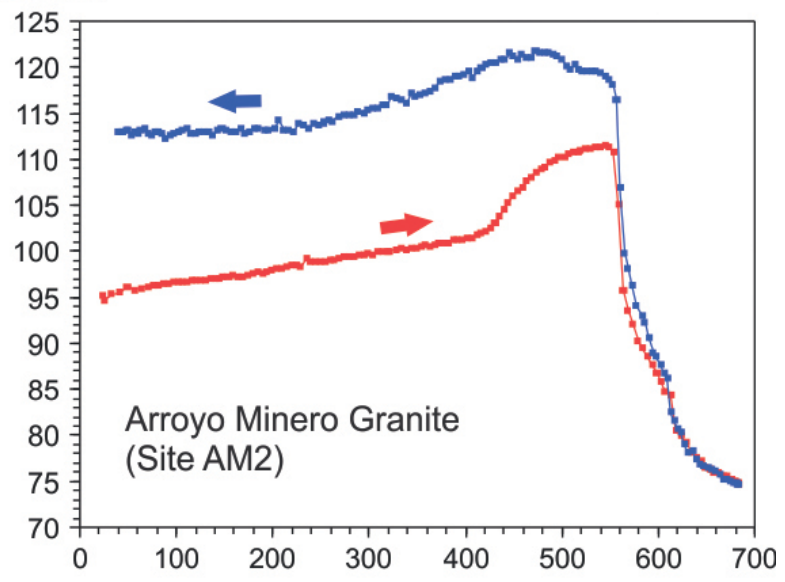

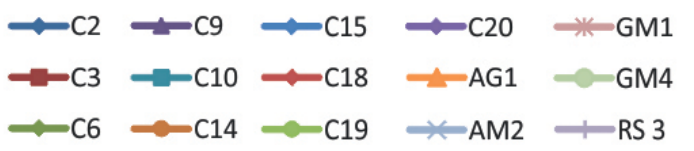

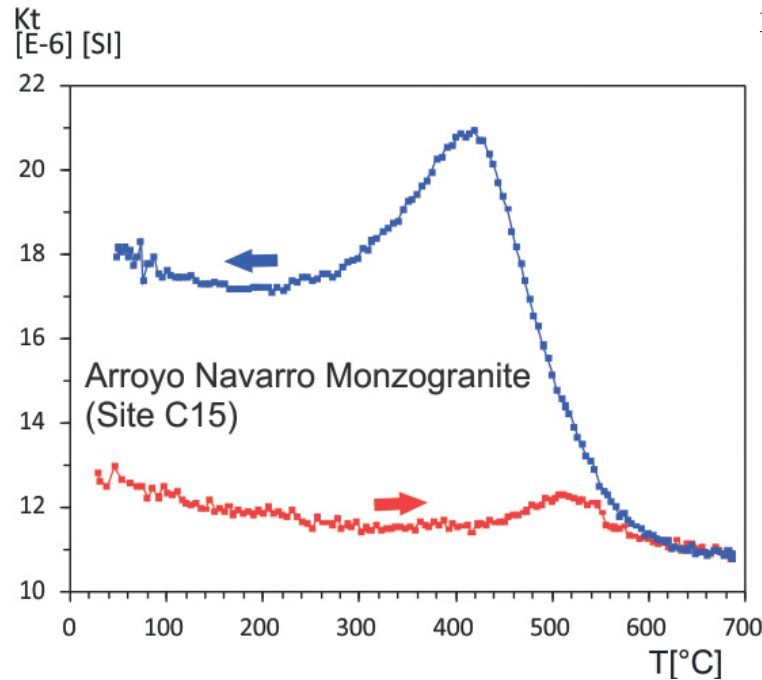

$\mathrm{D} \underset{[\mathrm{E}-6]}{\mathrm{Kt}}[\mathrm{SI}]$

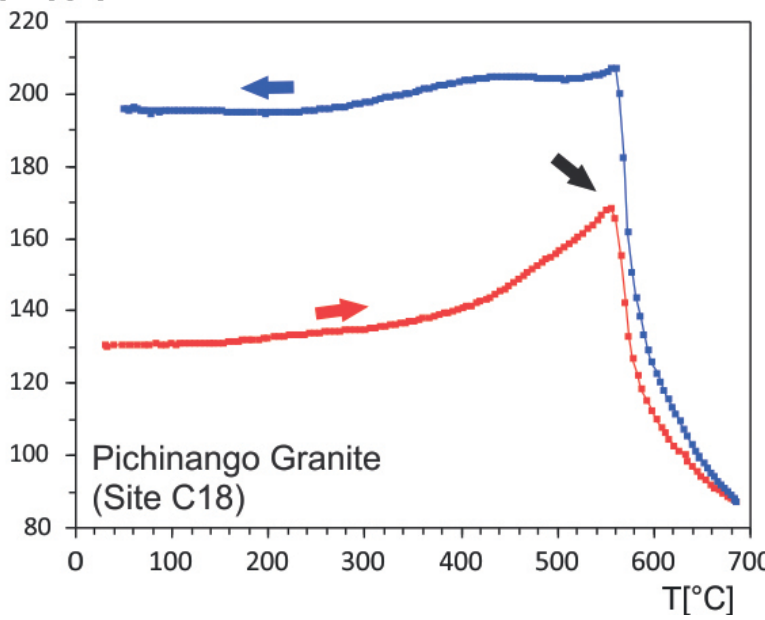

Figure 9. (A) $\mathrm{K}_{\mathrm{a}}$ versus temperature $(\mathrm{T})$ low temperatures curves. Note the marked hyperbola caused by paramagnetic minerals. The sites with a well-developed Verwey transition (black arrow) are C18, AM2 and GM4. (B, C and D) High temperature thermomagnetic curves for sites with a ferromagnetic fraction, as inferred from the isothermal remanent magnetization acquisition curves. Red lines correspond to heating curves, blue to cooling trajectories. Hopkinson peak (black arrow) is apparent in the high temperature curve of C18 site. All samples show slightly to clear irreversible curves with magnetite neoformation. Note: do not confuse Kmax with the $\mathrm{K}_{1}$ axis of Anisotropy of Magnetic Susceptibility (AMS). 
microstructures (magmatic zoning in plagioclase, chessboard and prismatic sub-grain development in quartz); and a biotite bearing granitic mylonite $(\mathrm{C} 2)$. The Cufré mylonite (C2, Fig. 11A) is a banded porphyroclast rock characterized by mega-crysts of perthitic microcline (with intragranular microfractures infilled with the matrix composition, development of subgrains and early crystals - biotite - trapped within the microfracture filling; all these features are pieces of evidence of cataclasis healed by melt in the sub-magmatic state) and smaller crystals of plagioclase (bent and deformed
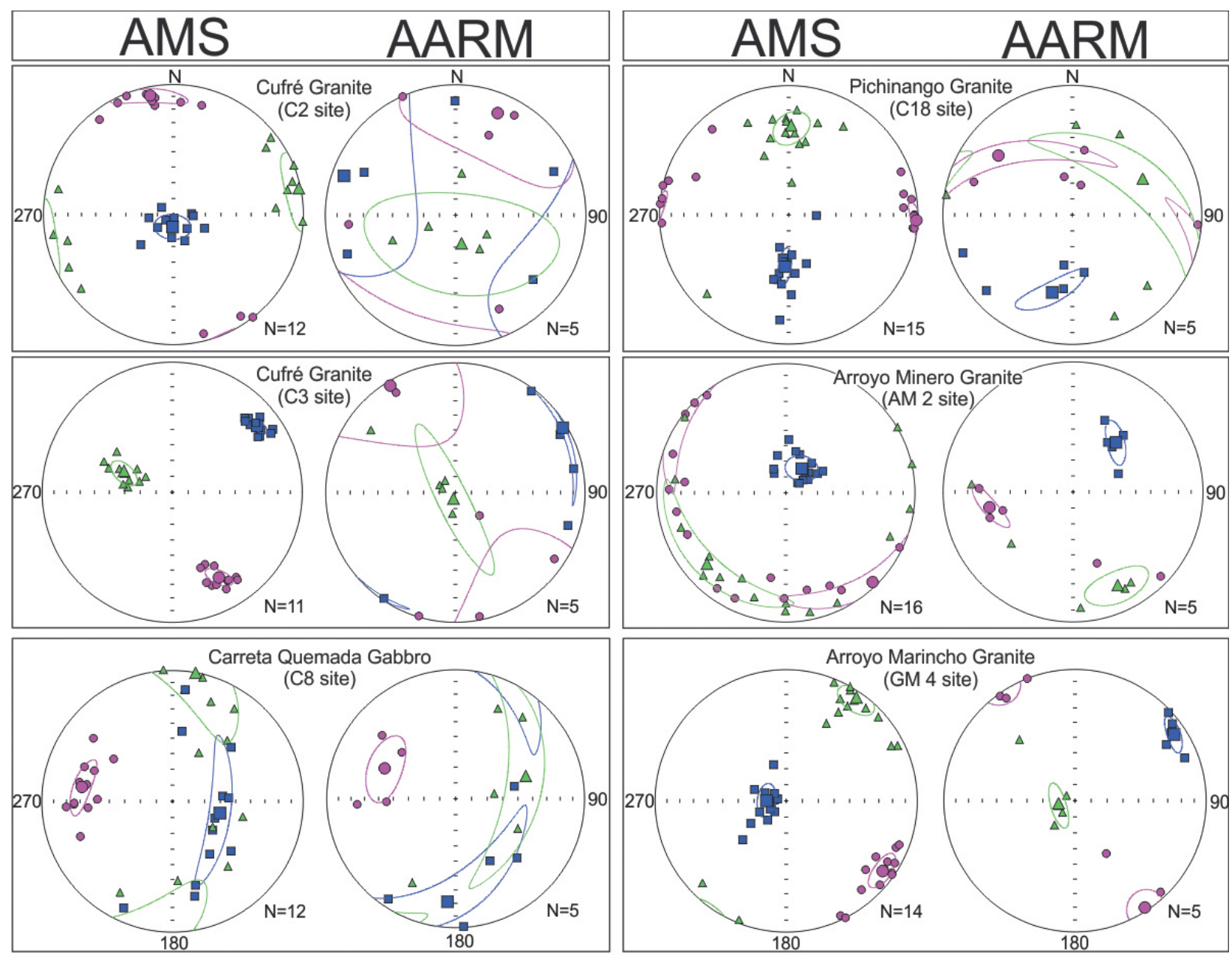

$\mathrm{K} 1 \square \mathrm{K} 2 \Delta \mathrm{K} 3 \mathrm{O}$

Figure 10. Stereographic projections for the main axes of the ellipsoid of Anisotropy of Magnetic Susceptibility (AMS) compared to the Anisotropy of Anhysteretic Remanent Magnetization (AARM) of C2, C3, C8, C18, AM2 and GM4 sites.

Table 2. Main Anisotropy of Magnetic Susceptibility (AMS) and Anisotropy of Anhysteretic Remanent Magnetization (AARM) statistical parameters for sites C2, C3, C8, C18, AM2 and GM4.

\begin{tabular}{lcccccccc}
\hline \multirow{2}{*}{ Site } & \multirow{2}{*}{ Intrusive } & \multirow{2}{*}{ Study } & $\begin{array}{c}\text { Kmean } \\
(\mathbf{S I})\end{array}$ & $\mathbf{P j}$ & $\mathbf{T}$ & $\mathbf{K}_{\mathbf{1}}$ & $\mathbf{K}_{\mathbf{2}}$ & $\mathbf{K}_{\mathbf{3}}$ \\
\hline \multirow{2}{*}{ C2 } & \multirow{2}{*}{ Cufré } & AMS & $1.95 \mathrm{E}-04$ & 1,047 & -0.079 & $184.1 / 82.3(11.4 / 7.8)$ & $79.2 / 2.0(18.3 / 11.2)$ & $348.9 / 7.5(19.1 / 5.5)$ \\
& & AARM & $5.74 \mathrm{E}-05$ & 1,156 & 0.574 & $289.4 / 10.2(64.3 / 43.6)$ & $168.9 / 70.5(63.8 / 32.2)$ & $22.4 / 16.4(49.5 / 35.0)$ \\
\hline \multirow{2}{*}{ C3 } & \multirow{2}{*}{ Cufré } & AMS & $1.63 \mathrm{E}-04$ & 1,041 & -0.05 & $52.0 / 18.1(6.3 / 3.1)$ & $291.4 / 57.3(10.3 / 5.2)$ & $151.3 / 26.3(10.1 / 3.9)$ \\
& & AARM & $1.20 \mathrm{E}-05$ & 1,469 & -0.83 & $58.9 / 3.7(38.0 / 2.1)$ & $192.9 / 84.6(54.5 / 9.6)$ & $328.6 / 3.9(55.7 / 31.7)$ \\
\hline \multirow{2}{*}{ C8 } & Carreta & AMS & $6.26 \mathrm{E}-03$ & 1,134 & 0.782 & $104.0 / 59.4(47.4 / 6.9)$ & $10.3 / 2.2(47.4 / 15.7)$ & $279.1 / 30.5(16.3 / 6.3)$ \\
& Quemada & AARM & $1.90 \mathrm{E}-02$ & 1,458 & 0.789 & $184.5 / 21.0(74.8 / 13.1)$ & $73.8 / 42.7(74.8 / 12.1)$ & $293.2 / 39.9(20.0 / 12.0)$ \\
\hline \multirow{2}{*}{ C18 } & \multirow{2}{*}{ Pichinango } & AMS & $3.79 \mathrm{E}-03$ & 1,104 & 0.075 & $184.3 / 56.9(12.3 / 3.8)$ & $1.7 / 33.0(13.0 / 9.0)$ & $92.4 / 1.2(10.0 / 4.0)$ \\
& & AARM & $3.96 \mathrm{E}-03$ & 1,116 & -0.607 & $194.5 / 38.1(25.1 / 6.7)$ & $64.3 / 39.5(72.8 / 13.5)$ & $308.7 / 27.6(72.7 / 7.0)$ \\
\hline \multirow{2}{*}{ AM2 } & Arroyo & AMS & $1.38 \mathrm{E}-03$ & 1,054 & -0.718 & $33.3 / 71.7(10.4 / 8.0)$ & $227.1 / 17.8(49.0 / 8.8)$ & $135.8 / 4.1(49.1 / 8.3)$ \\
& Minero & AARM & $8.90 \mathrm{E}-04$ & 1,121 & -0.16 & $40.9 / 48.2(14.2 / 5.7)$ & $154.9 / 20.0(17.6 / 11.9)$ & $259.6 / 34.9(16.5 / 4.9)$ \\
\hline \multirow{2}{*}{ GM4 } & Arroyo & AMS & $3.26 \mathrm{E}-03$ & 1,092 & 0.042 & $270.5 / 77.9(10.7 / 5.8)$ & $34.8 / 6.9(9.9 / 9.5)$ & $126.0 / 9.9(9.6 / 7.1)$ \\
& Marincho & AARM & $4.28 \mathrm{E}-02$ & 1,730 & -0.456 & $56.3 / 10.2(9.7 / 4.9)$ & $253.3 / 79.4(14.5 / 4.8)$ & $146.8 / 3.1(14.1 / 8.6)$ \\
\hline
\end{tabular}



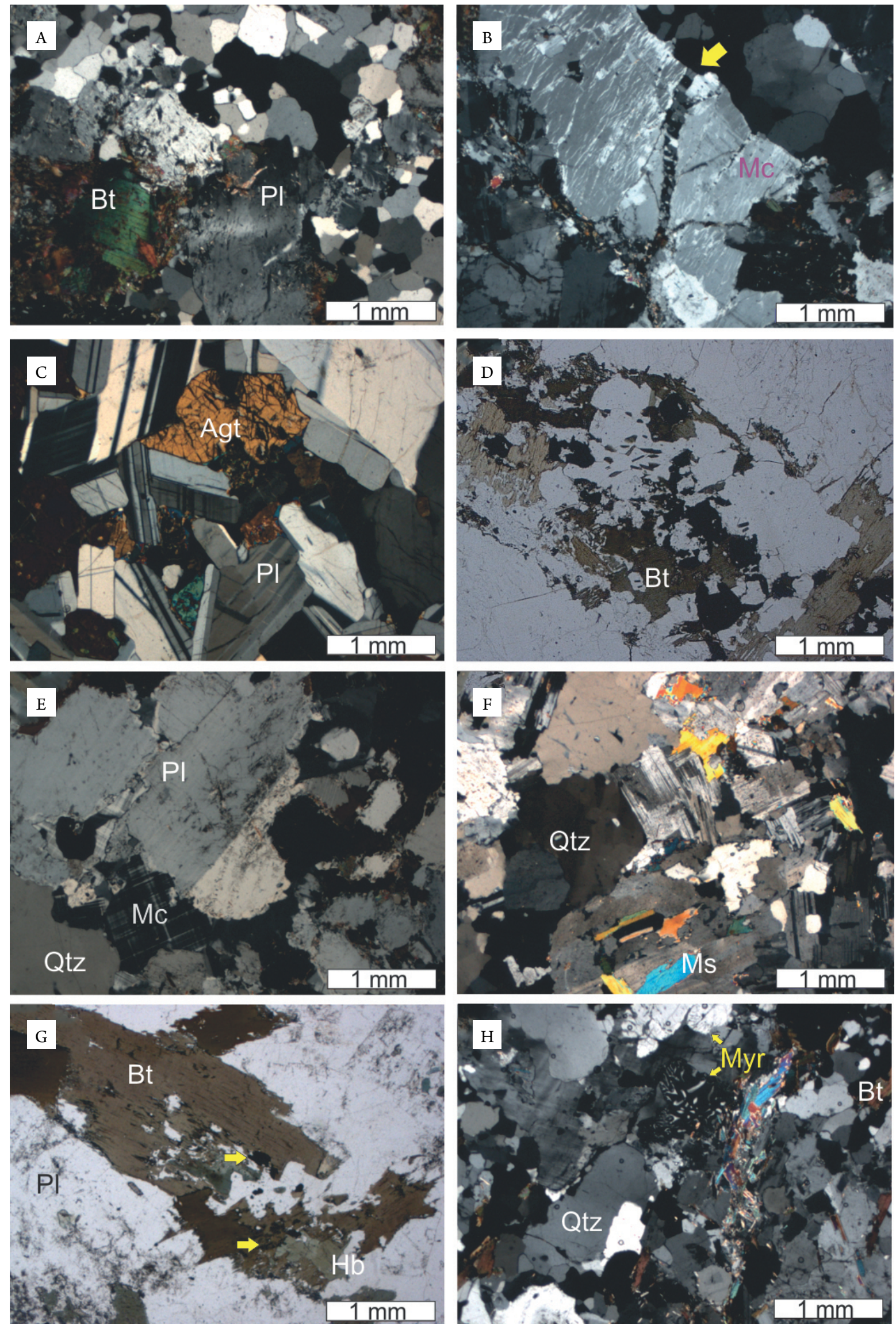

Bt: biotite; Pl: plagioclase; Mc: microcline; Agt: clinopyroxene; Qtz: quartz; Ms: muscovite; Myr: mirmequites.

Figure 11. Photomicrographs of thin sections of some of the studied bodies. (A) General texture of Cufré Granite (C2 site). (B) Cerro Albornoz Granite (C6 site): submagmatic fractures within pertitic microcline (yellow arrow). (C) Sub-ophitic texture of Carreta Quemada Gabbro in C8 site. (D) Pichinango Granite (C18 site) with crystals of biotite and opaque minerals. (E) Arroyo Colla Granite equigranular texture of the $\mathrm{C} 19$ site, with plagioclase, microcline and quartz. (F) San José Granite: equigranular texture in C10 site (San José Granite). (G) Tía Josefa Tonalite (C14 site), where crystals of biotite and hornblende are associated with opaque minerals (yellow arrows). (H) Arroyo Navarro Granite (C15 site) equigranular texture with crystals of plagioclase, quartz, muscovite, and biotite. 
twins evidence sub-magmatic intracrystalline plasticity conditions; Blenkinsop 2000) and biotite surrounded by irregular bands of statically and fully recrystallized quartz grains that define a somewhat planar fabric.

Passchier and Trouw (2001) explain static recrystallization as a result of sustained high $\mathrm{T}$ conditions or an overabundance of water along grain boundaries, which allowed recovery, grain boundary migration and recrystallization, after deformation stopped. C6 site corresponds to a mylonitic granite of grain to porphyroclast texture that was mapped in Preciozzi et al. (1985) as Cerro Albornoz Granite (Fig. 11B). It is a biotite and muscovite bearing granite, in which primary porphyroclasts K-feldspar (with subgrains), plagioclase and biotite aggregates are surrounded by pools of much smaller statically fully recrystallized pure quartz. This structure is similar in Cufré granites, but no foliation bands were described in this case.

Carreta Quemada subofitic Gabbro (C8, Fig. 11C), Pichinango Granite (C18, biotite-amphibole granite, Fig. 11D) and Arroyo Colla Granite (C19, Fig. 11E) that correspond to a biotite granite (whereas site $\mathrm{C} 20$ belongs to a biotite-amphibole rich monzogranite with titanite) showed little or no evidence of crystal deformation in the studied sites. The San José (C10, A-type Leucomonzogranite with primary muscovite, fluorite and zircon, Fig. 11F) exhibits parallel to chessboard sub-grain development in quartz, bent twins in plagioclase and wavy extinction and bent mica. These features in the presence of an igneous texture may hint at high $\mathrm{T}$ sub-solidus and sub-magmatic conditions (see Blenkinsop 2000). Tía Josefa Tonalite (C14, Fig. 11G) exhibits equigranular texture in which tabular zoned plagioclase crystals are partially oriented, indicating flow by melt displacement and crystal rotation without interaction to cause crystal plastic deformation. Local chessboard and sub-grain intracrystalline development in quartz as well as bulging, necking, and other local migration processes are present. Arroyo Navarro (C15, Fig. 11H) is an inequigranular to porphyritic texture granite that has slightly oriented biotite flakes and opaque minerals as main accessories. Wavy extinction in biotite indicates an intracrystalline plastic deformation.

No strict correlation has been found between deformation, as observed in thin sections, and anisotropy degrees or ellipsoidal shape. Nor has it been found in relation with bulk susceptibility. Only the $\mathrm{C} 3$ site in Cufré Granite shows a sub-horizontal magnetic lineation that is discordant with the subvertical lineations of all other sites in this body and that has been assigned to a proximity to the E-W Cufré shear zone. However, the fact that most intrusions do not show important signs of deformation nor that, when present, it corresponds to the syn to sub-magmatic stages, is consistent with a generally low AMS degree found in most sites (Tab. 1). In fact, the Arroyo Colla and Pichinango Granites and the Carreta Quemada Gabbro are among the bodies with higher values of $\mathrm{Pj}$ (Tab. 1), but none of them show textural signs of significant deformation. However, the latter two present the highest bulk susceptibility values falling into the "ferromagnetic domain". Thus, at least in these cases, the anisotropy degree may correlate with abundance of ferromagnetic minerals. For most of the other bodies, bulk susceptibilities fall well into the "paramagnetic" range. Some rock-magnetic results also suggest this parameter is probably governed by the paramagnetic fraction in these rocks. The presence of significant amounts of paramagnetic minerals, like micas and amphiboles, suggests that they are candidates to be main contributors to the magnetic fabric. It is common to find these minerals with euhedral to subhedral tabular shapes, suggesting a subtle shape preferred orientation anisotropy, from which an AMS ellipsoid representative of the average petrofabric of the rock is likely (Rochette et al. 1992, Borradaile and Henry 1997). Opaque minerals are found in virtually all thin sections (except for San José intrusive). On the other hand, as already indicated, high bulk susceptibility of Carreta Quemada, Tía Josefa, Isla Mala and Pichinango intrusives indicate full control of their magnetic fabric by ferromagnetic (s.l.) minerals.

\section{DISCUSSION AND INTERPRETATION}

Figures 12 and 13 display the distribution of magnetic lineations and foliations in all the studied Paleoproterozoic plutons plus those already reported by Rapalini et al. (2015) for San José and Arroyo Grande Belts. Regional location of each area depicted in these figures can be observed in Figure 1. Bulk susceptibility values generally in the paramagnetic domain, AARM indicative of lack of or scarce inverse or intermediate magnetic fabrics and broad consistency of magmatic foliations with mineral foliations as observed in some outcrops, suggest that at this stage of the reconnaissance study, most AMS lineations and foliations can be taken as broadly representative of the bulk petrofabric of the sampled intrusions.

Petrographic observations plus the magnetic fabric parameters suggest that tectonic deformation is generally mild or absent in most of the intrusives, except for individual sites in Cufré and Cerro Albornoz granites that show mylonitic textures. In some other plutons, deformation (if present) was probably acquired during magmatic to sub-magmatic flow conditions, with very low percentage of melt in the system or high $\mathrm{T}$ conditions. This suggests that AMS is likely controlled by magma intrusion and emplacement kinematics in most cases. As such, regionally coherent patterns may indicate homogeneous far-field stress regime during emplacement of these bodies, although the reconnaissance character of our study precludes to firmly establish the internal magnetic fabric pattern for each intrusion individually. Regarding those sites of the Cufré and Cerro Albornoz granites with mylonitic textures, their magnetic fabric is likely governed by the orientation of biotite and feldspar porphyroclasts parallel to the mylonitic fabric that coincides with the orientation of Cufré Shear Zone. Although precise radiometric datings have not been available for all sampled plutons, those already obtained (Santos et al. 2003, Hartmann et al. 2000, 2008, Peel and Preciozzi 2006, Oyhantçabal et al. 2018) suggest that most, if not all, were intruded during the same magmatic cycle, roughly between 2.1 and $2.0 \mathrm{Ga}$ (see also Franceschinis et al.2019). The Cufré and Paso Lugo Shear Zones and their associated faults (Fig. 1B) have not been dated yet. However, the comparable MSZ in southernmost Uruguay that affects the 2.1-2.2 Ga Montevideo Formation, yielded $\mathrm{K}$-Ar cooling ages in muscovite between 1.9 and $2.05 \mathrm{Ga}$ 
(Oyhantçabal et al. 2018). These ages are consistent with an Orosirian crustal cooling and cratonization of Piedra Alta terrane. After a period of accretion, deformation and metamorphism at about 2.2-2.1 Ga that led to the Granitic-Gneissic terrains and meta-volcanic and metasedimentary belts, intrusion of the late- to post-orogenic bodies studied here can be seen as in the final stages of such crust stabilization. Deformation at such stage was probably concentrated along the meta-volcanic and metasedimentary belts and as cooling proceeded mainly remained as more fragile deformation along discrete (although probably complex) E-W trending shear zones (as Paso Lugo, Cufré, Mosquitos, Colonia, etc.).

Our study must be considered as a reconnaissance one, since a proper mapping of the internal fabric of each sampled
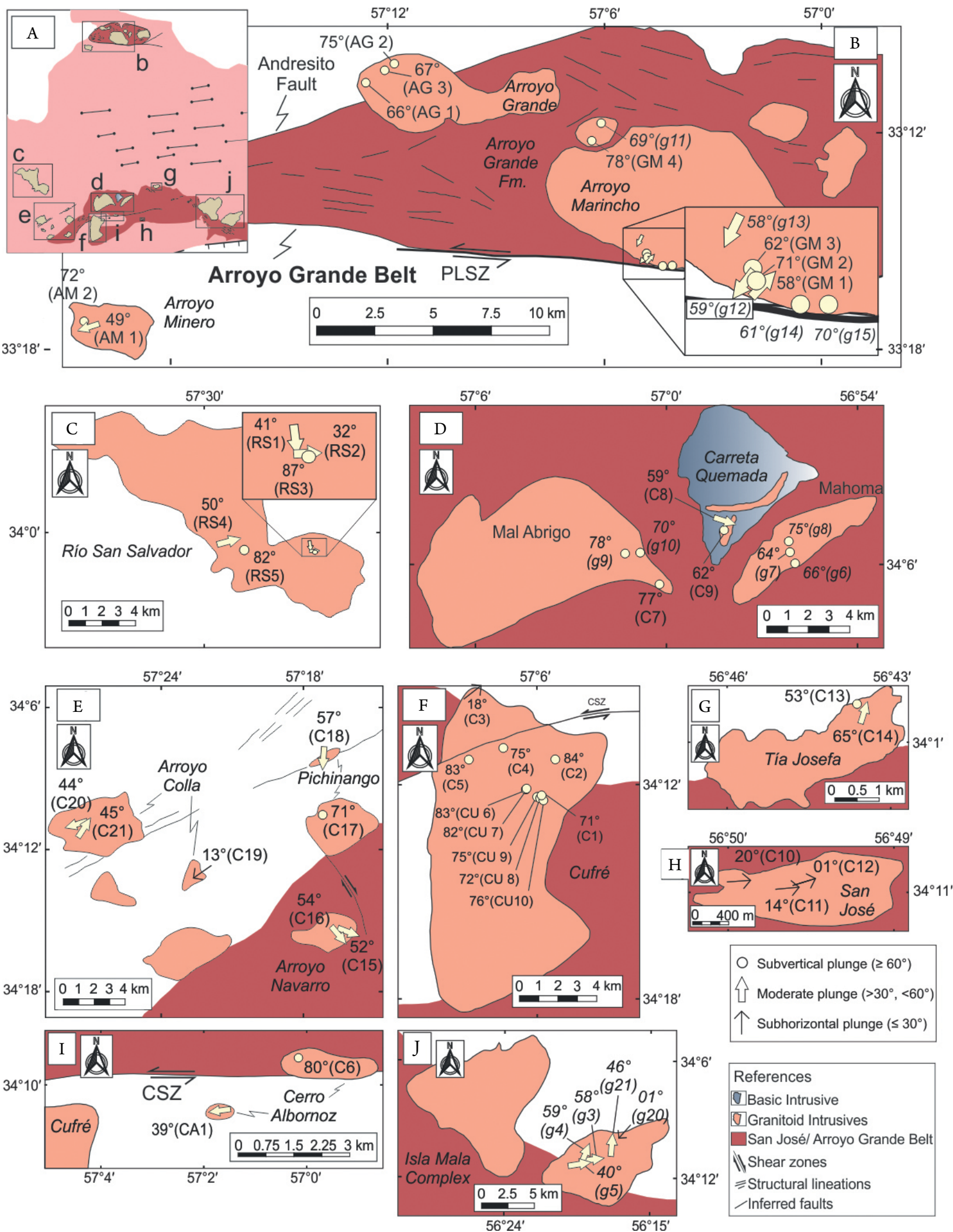

Subvertical plunge $\left(\geq 60^{\circ}\right)$

仓 Moderate plunge $\left(>30^{\circ},<60^{\circ}\right)$

$\uparrow$ Subhorizontal plunge $\left(\leq 30^{\circ}\right)$

\section{References}

(D)Basic Intrusive

[7] Granitoid Intrusives

$\square$ San José/ Arroyo Grande Belt

1IShear zones

¿Structural lineations

-Inferred faults

Figure 12. Magnetic lineations of Paleoproterozoic intrusives studied in this paper (italics) and previously determined values in Rapalini et al. (2015). 
pluton will be needed to fully unravel their tectonomagmatic history. Similarly, precise geochronological control of each single pluton (work in progress) will certainly shed light on the time span of the magmatic cycle, as well as the chronological relations among the intrusions. Despite these drawbacks, the available information on age, microstructures and magnetic fabrics may be relevant to figure out a broad picture of the regional tectonic control and possible mechanisms acting during this important magmatic cycle in Piedra Alta terrane.

Some main observations from the obtained data include the fact that magnetic lineations are in most cases sub-vertical or of high angle (Fig. 12). This pattern is shown by the Cufré, Cerro Albornoz, Mal Abrigo, Carreta Quemada, Mahoma, Pichinango, Tía Josefa, Arroyo Grande and Arroyo Marincho
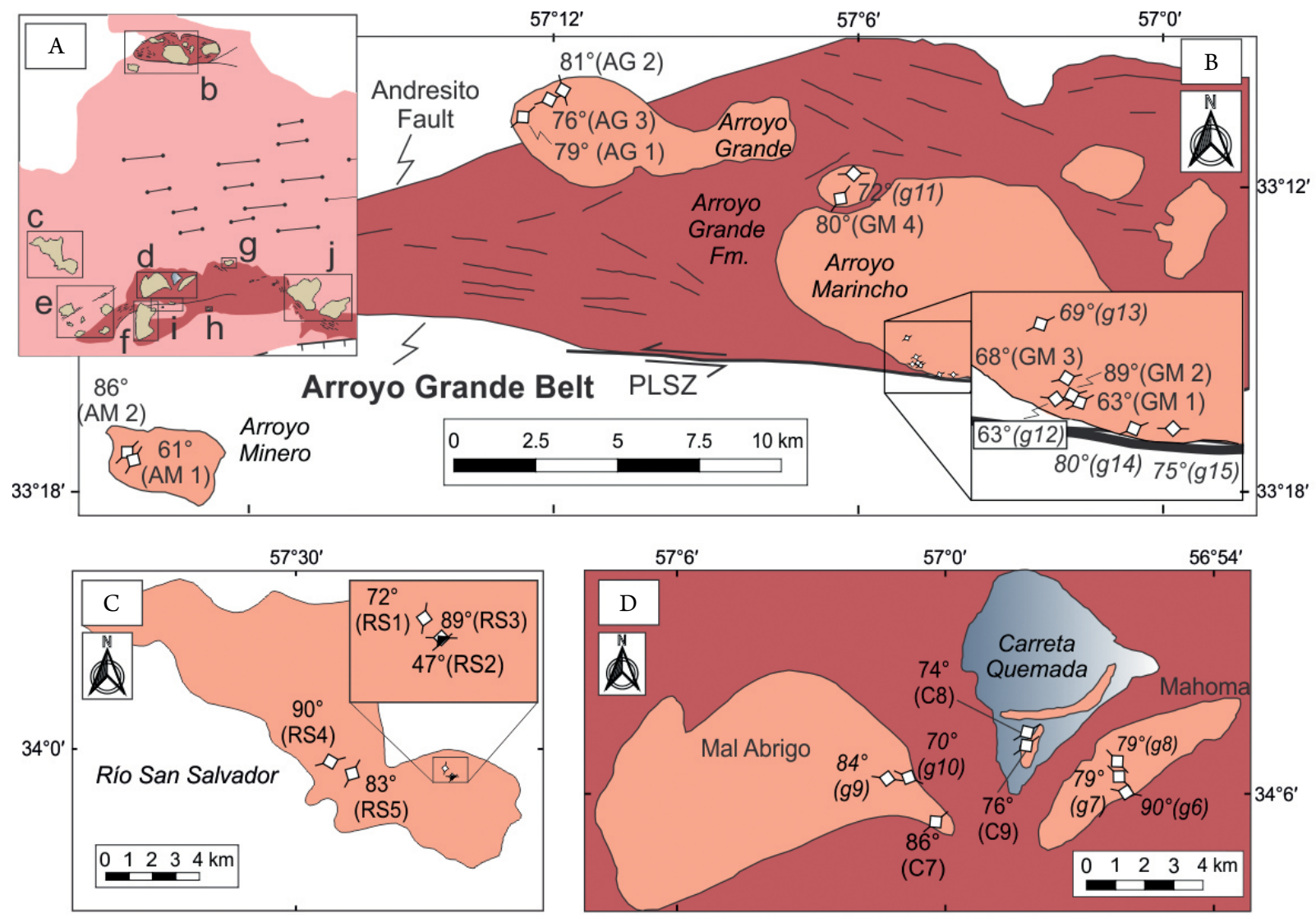

$57^{\circ} 0^{\prime}$

$56^{\circ} 54^{\prime}$
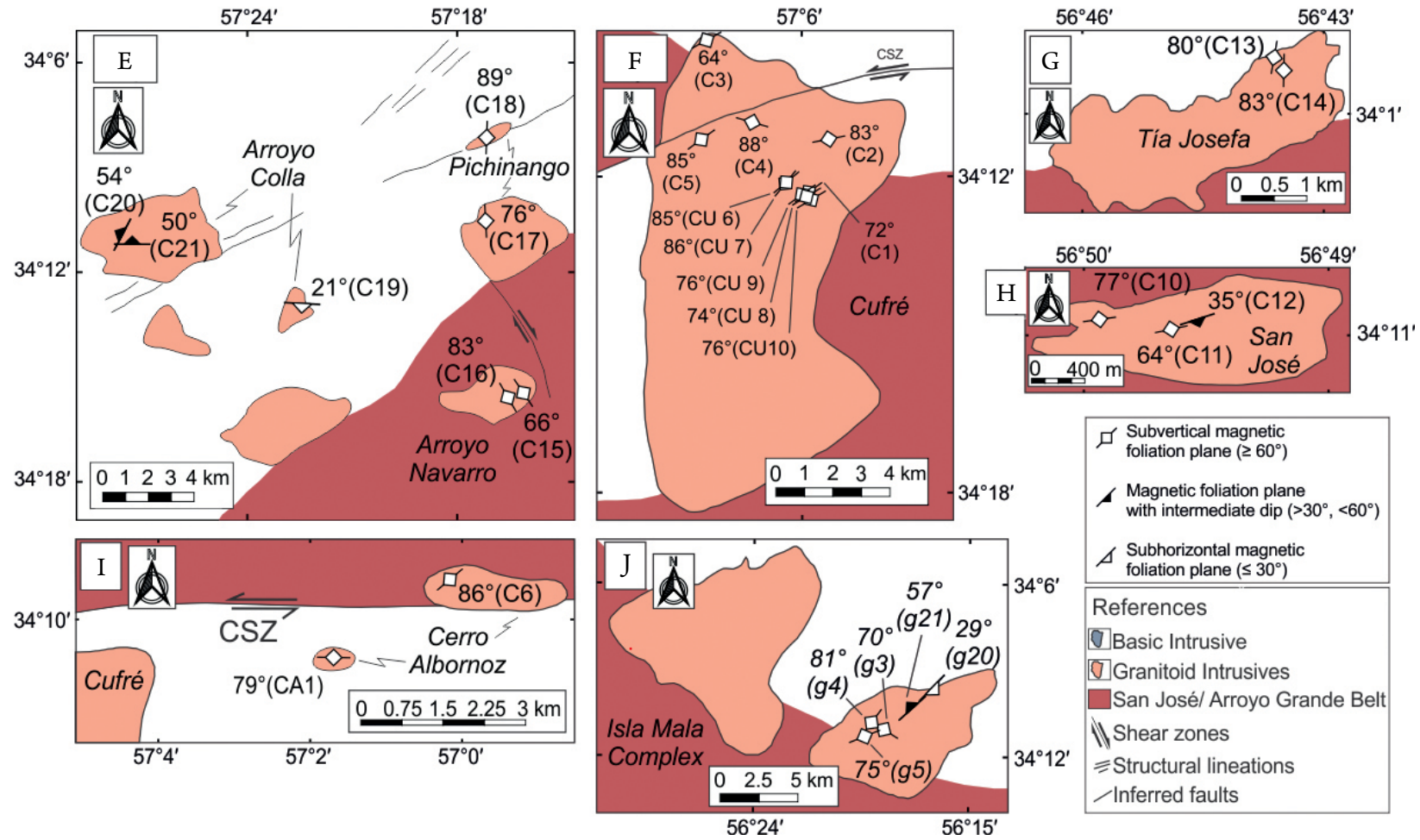

\begin{tabular}{|l|}
\hline$\checkmark \begin{array}{l}\text { Subvertical magnetic } \\
\text { foliation plane }\left(\geq 60^{\circ}\right)\end{array}$ \\
$\begin{array}{l}\text { Magnetic foliation plane } \\
\text { with intermediate dip }\left(>30^{\circ},<60^{\circ}\right)\end{array}$ \\
$\Delta \begin{array}{l}\text { Subhorizontal magnetic } \\
\text { foliation plane }\left(\leq 30^{\circ}\right)\end{array}$ \\
\hline References \\
0 Basic Intrusive \\
$\square$ Granitoid Intrusives \\
$\square$ San José/ Arroyo Grande Belt \\
$\mathbb{1}$ Shear zones \\
三Structural lineations \\
- Inferred faults \\
\hline
\end{tabular}

Figure 13. Magnetic foliations of Paleoproterozoic intrusives studied in this paper (italics) and previously determined values in Rapalini et al. (2015). 
plutons, and to a lesser extent for the Arroyo Navarro, Arroyo Minero, Río San Salvador and Isla Mala intrusions. In magmatic fabrics, lineations are generally interpreted (Paterson et al. 1989) as recording final stages of magma kinematics. We have already suggested that magnetic fabrics in these late- to post-orogenic plutons of San José and Arroyo Grande belts are in most cases of magmatic origin; therefore, the dominance of subvertical to high-angle magnetic lineations, plus their generally equant shapes, suggest that intermediate to deep structural levels of the plutons are exposed (Bouchez 1997) and these bodies probably intruded in an extensional system that permitted, at least up to a certain degree, the magma free ascent. This is consistent with subvertical magmatic features like elongated mafic enclaves as observed in the field. The 3D shape of these bodies is unknown, as no detailed gravimetric studies (Améglio and Vigneresse 1999, D'Eramo et al. 2006) have been carried out yet. Only the very small San José pluton shows low-angle magnetic lineations of E-W trend, parallel to the regional structural fabric and the main shear zones (i.e., Cufré Shear Zone, located about $10 \mathrm{~km}$ North of the pluton). Sporadic E-W to NE-SW low-angle lineations were observed in some plutons (Cufré, Cerro Albornoz, Isla Mala) close to their margins, which suggest localized effects associated with the pluton borders. However, in the case of Cufré (C3 site) and Cerro Albornoz (CA1 site) plutons, localized deformation related to the activity of the nearby Cufré Shear Zone may be an alternative explanation for the E-W sub-horizontal magnetic lineations at those sites.

Magnetic foliation (Fig. 13) is subvertical $\left(\geq 60^{\circ}\right)$ in most of the studied plutons (Arroyo Marincho, Arroyo Grande, Arroyo Minero, Río San Salvador, Pichinango, Arroyo Navarro, Mal Abrigo, Carreta Quemada, Mahoma, Cerro Albornoz,
Cufré, San José, Tía Josefa, and Isla Mala). Most plutons show a well-defined E-W to NE-SW magnetic foliation only locally disturbed. It is in some cases associated with border effects (e.g., Arroyo Grande, Isla Mala). However, Pichinango and Arroyo Navarro Granites, located at the Western extreme of San José Belt, show a dominantly N-S to NW-SE foliation sub-parallel to the N-S shear zone that limits this belt (Fig. 1B). Tía Josefa Tonalite also shows a N-S foliation being located close to the Northern border of the metamorphic belt and relatively isolated from other bodies. Another body that diverges from the dominant E-W to NE-SW subvertical foliation pattern is the Arroyo Colla granite, in which magnetic foliations present moderate to shallow plunges, but with similar strikes to the dominant E-W to NE-SW trend. This pluton is the westernmost exposed along the San José Belt, and actually it is not supposed to be intruding the meta volcanic-sedimentary belt but the granite-gneiss terranes, although contacts have not been exposed. Whether the different encasing lithology is affecting the internal structure of this body, the emplacement kinematics and its shapes or it is similar to those located to the East but exposed at higher structural levels (i.e., foliations reflecting magma kinematics near the top of the bodies) should be investigated with further sampling and detailed gravity surveys. As with lineations, magnetic foliations tend to show little variability within the plutons, except perhaps for Arroyo Colla Granite.

The clearly dominant pattern ofE-W to NE-SW foliations and subvertical lineations has been illustrated in Fig. 14 and must be considered a first order pattern of these Paleoproterozoic intrusions. The foliation trend is consistent with the general structural grain of Piedra Alta terrane (e.g., Bossi et al. 1993, Oyhantçabal et al.2011 and references therein). This is shown by the geographic

\section{K1 mean directions}

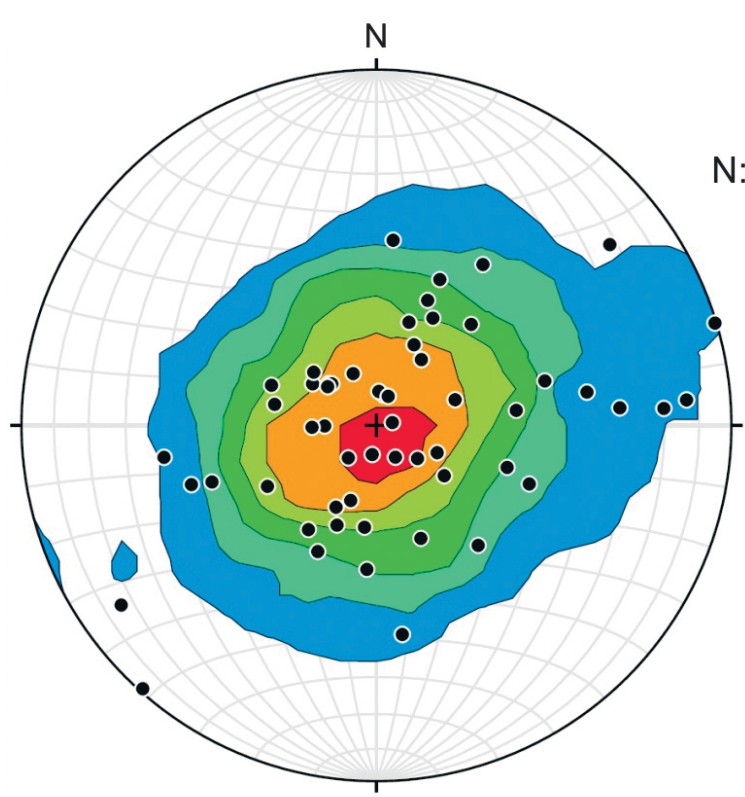

K1 mean vector: trend: $94.3^{\circ}$ plunge: $85.5^{\circ}$

\section{K3 mean directions}

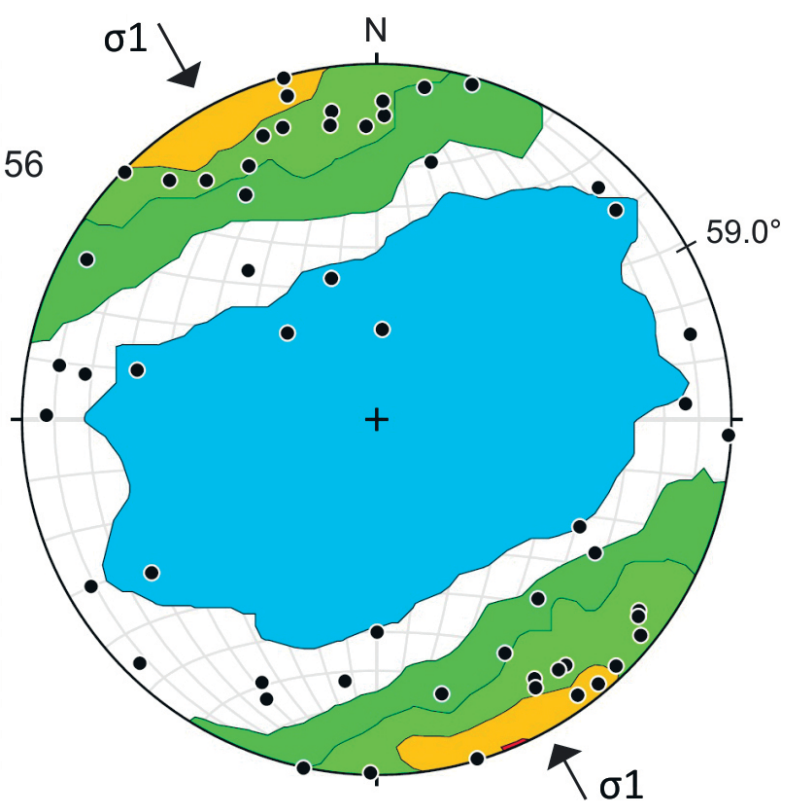

Mean foliation plane: $59.0^{\circ} / 88.8^{\circ} \mathrm{SE}$

Figure 14. Frequency contour curves for $\mathrm{K}_{1}$ and $\mathrm{K}_{3}$ of all sampled sites. It also includes the $\mathrm{K}$ mean of the sites published in Rapalini et al. (2015). On the left (right), mean $\mathrm{K}_{1}\left(\mathrm{~K}_{3}\right)$ for each site. Note the subvertical attitude of most lineations and the dominant sub-horizontal $\mathrm{K}_{3}$ defining an NE-SW foliation plane. Mean $\mathrm{k} 1$ and $\mathrm{k} 3$ values are indicated, as well as interpreted mean regional stress field $(\sigma 1)$ compatible with this distribution. For the contour curves, Stereonet v.9.9.6 software was used (Allmendinger et al. 2013, Cardozo and Allmendiger 2013). 
expression of supracrustal metamorphic belts that bound the (Florida) Granitic-Gneissic domains (Hasui et al. 1975; Fig. 1B) and may represent the final stages of microcontinental assembly and/or closure of back-arc basins. Similar trends are found in the basement of Tandilia System in Argentina (Cingolani 2011 and references therein), where a Rhyacian suture (El Cortijo Complex, Teruggi et al. 1988, Chernicoff et al. 2014) has been described with a roughly E-W trend. Similar structural grain has also been interpreted by Chernicoff et al. (2014) for covered areas of Río de la Plata Craton in the Province of Buenos Aires, from regional magnetic surveys. The magnetic foliation is also consistent with the elongate distribution of most of these bodies, which are approximately aligned along an E-W belt. This structural grain also conditioned the much later intrusion of the $1790 \pm 5$ Ma Florida tholeiitic dyke swarm (Halls et al. 2001, Teixeira et al. 2013, Fig. 1B), which is the last major geologic event that took place in Piedra Alta terrane.

These observations suggest that the study intrusions occurred as the final stages of continental assembly of Río de la Plata Craton, a process that was governed by accretion of several crustal blocks by closing of small oceans and/or back-arc basins between juvenile crustal blocks. This process occurred through a series of collisions in a N-S direction (present-day coordinates), giving birth to the dominant structural grain of Río de la Plata craton. Final stages of the orogenic processes in which postcollisional transtensional stress regimes dominated probably led to the intrusion of numerous igneous bodies. This is consistent with the geochemical signature of this magmatism (Oyhantçabal et al. 2011), which locates it in the post-orogenic to collisional fields. Orogenic processes ended between 2.1 and $2.0 \mathrm{Ga}$, as well as most of the magmatism. Extension, or more likely transtension, due to orogenic relaxation, produced accommodation space for most plutons to intrude sub-vertically, as suggested by high angle lineations and foliations. The E-W distribution of most of the plutons and the similar trend of magnetic foliations are consistent with this picture.

The presence of E-W strike-slip systems approximately coeval to the intrusion of these bodies (like the Cufré and Paso Lugo shear zones, Fig. 1B), their aligned distribution along the E-W metamorphic belts, and the highly dominant subvertical and E-W to NE-SW trending magnetic foliations point to an association of magmatic emplacement and transtensional deformation along these belts. This pattern is consistent with much better developed E-W mega-shear zones in the Tandilia system of Río de la Plata craton in Argentina (Cingolani et al. 2002). Sub-horizontal E-W lineations in San José pluton (that shows evidence of low temperature deformation) and isolated sites close to the shear zone in Cufré and Cerro Albornoz bodies, as well as the $\mathrm{N}-\mathrm{S}$ trending subvertical foliations of the small Tía Josefa Tonalite and Pichinango Granite, are consistent with these ideas. The latter two plutons could represent intrusions in small transtensional pull-apart sectors along the main shear zone.

The tectonic framework for Río de la Plata Craton during its amalgamation is still unknown. In addition, the possibility that it was part of the assembly of a larger continent (i.e., Atlantica, Rogers 1996, Rapalini et al. 2015, Franceschinis et al.2019) is likely considering similar tectonic processes and geochronologic framework with other cratons (Congo - São Francisco, West Africa, Guyana). However, no evidence has been proposed yet in favor of a "dome and keel" tectonics for Piedra Alta terrane as in other cratons. A link between the location and structure of the volcano sedimentary belts (named greenstone belts) and the post-collisional granites studied herein may suggest that such structural configuration may have taken place in this craton too. Further work on the origin of the Granite-Gneissic Complexes will certainly shed light on the processes involved in the tectono-magmatic events that led to the building of this continent.

\section{CONCLUSIONS}

Reconnaissance magnetic fabric studies supported by rock magnetic experiments and petrographic observations in 14 Paleoproterozoic intrusive bodies, sampled at 41 sites along San José and Arroyo Grande belts on Piedra Alta terrane, plus previous data from other four intrusions ( 15 sites) in the same belts, permitted to determine that most of these bodies suffered low to null internal low temperature deformation. The magnetic fabrics are, therefore, mostly interpreted as mainly determined by final magma displacement and emplacement kinematics in most bodies. Subvertical lineations dominate in most intrusions, suggesting an extensional regional field controlling the magma ascent. Magnetic foliations are dominantly subvertical and E-W to NE-SW trending. This is consistent with the main structural grain of Piedra Alta terrane, the geographic distribution of plutons, the configuration of the volcano-sedimentary metamorphic belts, and the trend of major mega-shears (such as Cufré and Paso Lugo fault zones). The fact that these strikeslip zones were active approximately coevally with the study intrusions is consistent with a modal of local transtensional regimes, including some possible pull-apart zones, controlling the intrusion of many of these plutons. Regional stress field as inferred from the studied plutons is consistent with their interpretation as late to post-orogenic intrusions associated with crustal stabilization after crustal forming and accretionary processes, which led to the formation of Río de la Plata Craton (Piedra Alta terrane) in the middle Paleoproterozoic.

\section{ACKNOWLEDGMENTS}

This study was supported by Universidad de Buenos Aires (Grant 20020130100465BA) and Consejo Nacional de Investigaciones Científicas y Técnicas - CONICET (PIP112201101-00294 and PUE-IGEBA-2016). Anisoft and Cureval programs (AGICO SA) were used to analyze the data. Carlos A. Vásquez and Matías Naselli kindly collaborated during the preparation of samples and running of thermomagnetic curves. Discussions of some rock magnetic results are also acknowledged. Comments by B. Henry on a previous version of this manuscript are also contributions. We also thank constructive but thorough reviews by L. Pinotti and an anonymous reviewer, who significantly improved the final version of the manuscript. This is a contribution to the International Geological Correlation Programme (IGCP) project 648. 


\section{ARTICLE INFORMATION}

Manuscript ID: 20200002. Received on: 01/09/2020. Approved on: 03/09/2020.

P. F. wrote the first draft of the manuscript, prepared all the figures, and participated in the field work. A. R. improved the manuscript through corrections and suggestions, project administration, funding acquisition and participated in the field work. L. S. B. improved the manuscript through corrections and suggestions, provided advisership regarding Uruguayan geology and participated in the field work. C. M. D. improved the manuscript through corrections and suggestions, made the observations of the petrographic thin sections and participated in the field work. F. M. improved the manuscript through corrections and suggestions, collaborated during preparation of samples and participated in the field work.

Competing interests: The authors declare no competing interests.

\section{REFERENCES}

Aguilar C., Alkmim F.F., Lana C., Farina F. 2017. Palaeoproterozoic assembly of the São Francisco craton, SE Brazil: New insights from U-Pb titanite and monazite dating. Precambrian Research, 289:95-115. https:// doi.org/10.1016/j.precamres.2016.12.001

Alkmim F.F., Marshak S. 1998. Transamazonian Orogeny in the Southern São Francisco Craton Region, Minas Gerais, Brazil: evidence for Paleoproterozoic collision and collapsein the Quadrilátero Ferrífero. Precambrian Research, 90:29-58.

Allmendinger R.W., Cardozo N.C., Fisher D. 2013. Structural Geology Algorithms: Vectors \& Tensors. Cambridge: Cambridge University Press, 289 p.

Almeida F.F.M., Amaral G., Cordani U.G., Kawashita K. 1973. The Precambrian evolution of the South American cratonic margin, south of the Amazon River. In: Nairn A.E., Stehli F.G. (Eds.). The Ocean Basins and Margins. New York: Plenum Publishing, v. 1, p. 411-446.

Améglio L., Vigneresse J.L. 1999. Geophysical imaging of the shape of graniticintrusions at depth: a review. Geological Society, Special Publications, 168:39-54. https://doi.org/10.1144/GSL.SP.1999.168.01.04

Basei M.A.S., Sánchez Bettucci L., Peel E., Preciozzi F. 2016. LAICPMS $\mathrm{U}-\mathrm{Pb}$ zircon ages from basement and metamorphic cover of Piedra Alta Terrane, Rio de la Plata Craton, Uruguay. In: Gaucher C., Montano J. (Eds.), VIII Congreso Uruguayo de Geología. Montevideo, p. 117.

Blenkinsop T.G. 2000. Deformation Microstructures and Mechanisms in Minerals and Rocks. Elsevier, New York. 164 pp.

Bolle O., Diot H., Trindade R.I.F. 2003. Magnetic fabrics in the Holum granite (Vest-Agder, southernmost Norway): implications for the late evolution of the Sveconorwegian (Grenvillian) orogen of SW Scandinavia. Precambrian Research, 121(3-4):221-249. https://doi.org/10.1016/ S0301-9268(03)00013-5

Bolle O., Diot H., Vander Auwera J., Dembele A., Schittekat J., Spassov S., Ovtcharova M., Schaltegger, U. 2018. Pluton construction and deformation in the Sveconorwegian crust of SW Norway: Magnetic fabric and U-Pb geochronology of the Kleivan and Sjelset granitic complexes. Precambrian Research, 305:247-267. https://doi.org/10.1016/j.precamres.2017.12.012

Borradaile G.J., Henry B. 1997. Tectonic applications of magnetic susceptibility and its anisotropy. Earth Science Reviews, 42(1-2):49-93. https://doi.org/10.1016/S0012-8252(96)00044-X

Bossi J., Preciozzi F., Campal N. 1993. Predevoniano en el Uruguay I: Terreno Piedra Alta. Uruguai: Dirección Nacional de Minería y Geología.

Bouchez J.L. 1997. Granite is never isotropic: an introduction to AMS studies of granitic rocks. In: Bouchez J.L., Hutton D.W.H., Stephens W.E. (Eds.). Granite: From Segregation of Melt to Emplacement Fabrics. Dordrecht: Kluwer Acad. Publ., p. 95-112.

Bouchez J.L., Delas C., Gleizes G., Nédélec A., Cuney M. 1992. Submagmatic microfractures in granites. Geology, 20(1):35-38. https://doi. org/10.1130/0091-7613(1992)020\%3C0035:SMIG\%3E2.3.CO;2

Cardozo N., Allmendinger R.W. 2013. Spherical projections with OSXStereonet. Computers \& Geosciences, 51:193-205. https://doi. org/10.1016/j.cageo.2012.07.021

Chernicoff C.J., Zappettini E.O., Peroni J. 2014. The Rhyacian El Cortijo suture zone: Aeromagnetic signature and insights for the geodynamic evolution of the southwestern Rio de la Plata craton, Argentina. Geoscience Frontiers, 5(1):43-52. https://doi.org/10.1016/j.gsf.2013.04.004

Cingolani C.A. 2011. The Tandilia system of Argentina as a southern extension of the Río de la Plata craton: An overview. International Journal of Earth Sciences, 100(2):221-242. https://doi.org/10.1007/ s00531-010-0611-5
Cingolani C.A., Hartmann L.A., Santos J.O.S., MCNaughton N.J. 2002. $\mathrm{U}-\mathrm{Pb}$ SHRIMP dating of zircons from the Buenos Aires complex of the Tandilia belt, Rio de La Plata craton, Argentina. In: Congreso Geológico Argentino, 15., 2002, El Calafate. Anais..., p. 149-154.

Delor C., Lahondère D., Egal E., Lafon J.M., Cocherie A., Guerrot C., Rossi P., Truffert C., Théveniaut H., Phillips D., de Avelar V.G. 2003. Transamazonian crustal growth and reworking as revealed by the 1: 500 000-Scale Geological Map of French Guiana. $2^{\text {nd }}$ ed. Géologie de la France, 2-3-4:5-57.

D’Eramo F.J., Pinotti L.P., Tubía J.M., Vegas N., Aranguren A., Tejero R., Gómez D. 2006. Coalescence of lateral spreading magma ascending through dykes: a mechanism to form a granite canopy (El Hongo pluton, Sierras Pampeanas, Argentina). Journal of the Geological Society of London, 163(5):881-892. https://doi.org/10.1144/0016-764905-060

De Saint-Blanquat M., Law R.D., Bouchez J.L., Morgan S.S. 2001. Internal structure and emplacement of the Papoose Flat pluton: An integrated structural, petrographic, and magnetic susceptibility study. Geological Society of America Bulletin, 113(8):976-995. https://doi. org/10.1130/0016-7606(2001)113<0976:ISAEOT>2.0.CO;2

De Waele B., Johnson S.P., Pisarevsky S.A. 2008. Palaeoproterozoic to Neoproterozoic growth and evolution of the eastern Congo Craton: its role in the Rodinia puzzle. Precambrian Research, 160(1-2):127-141. https:// doi.org/10.1016/j.precamres.2007.04.020

Dunlop D.J., Ozdemir O. 1997. Rock Magnetism: Fundamentals and Frontiers. Cambridge University Press, New York, pp. 573.

Eby N. 1992. Chemical subdivision of the A-type granitoids: petrogenetic and tectonic implications. Geology, 20(7):641-644. https://doi. org/10.1130/0091-7613(1992)020\%3C0641:CSOTAT\%3E2.3.CO;2

Ferré E. 2002. Theoretical models of intermediate and inverse AMS fabrics. Geophysical Research Letters, 29(7):31-34. https://doi. org/10.1029/2001GL014367

Franceschinis P.R., Rapalini A.E.,Escayola M.P.,Luppo T.2016. Paleomagnetic studies on the late Ediacaran - Early Cambrian Puncoviscana and the late Cambrian Campanario formations, NW Argentina: New paleogeographic constraints for the Pampia terrane. Journal of South American Earth Sciences, 70:145-161. https://doi.org/10.1016/j.jsames.2016.04.007

Franceschinis P.R., Rapalini A.E., Sánchez Bettucci L., Martínez Dopico C., Milanese F.N. 2019. Paleomagnetic confirmation of the "unorthodox" configuration of Atlantica between 2.1 and 2.0 Ga. Precambrian Research, 334:105447. https://doi.org/10.1016/j.precamres.2019.105447

Halls H.C., Campal N., Davis D.W., Bossi J. 2001. Magnetic studies and $\mathrm{U}-\mathrm{Pb}$ geochronology of the Uruguayan dike swarm, Rio de la Plata Craton, Uruguay: paleomagnetic and economic implications. Journal of South American Earth Sciences, 14(4):349-361. https://doi.org/10.1016/ S0895-9811(01)00031-1

Hartmann L.A., Bossi J., Santos J.O.S., McNaughton N.J., Piñeyro D. 2008 Geocronología U-Pb SHRIMP en circones del gabro Róspide en el cinturón Paleoproterozoico San José, Terreno Piedra Alta, Uruguay: una prueba geocronológica de magmas coetáneos. Revista de la Sociedad Uruguaya de Geología, 15:40-53.

Hartmann L.A., Piñeyro D., Bossi J., Leite J.A.D., McNaughton N.J. 2000. Zircon U-Pb SHRIMP dating of Paleoproterozoic Isla Mala granitic magmatism in the Rio de la Plata Craton, Uruguay. Journal of South American Earth Sciences, 13(1-2):105-113. https://doi.org/10.1016/ S0895-9811(00)00018-3

Hasui Y., Sadowski G.R., Suguio K., Fuck G.F. 1975. The Phanerozoic tectonic evolution of the western Minas Gerais State. Anais da Academia Brasileira de Ciências, 47(3-4):431-438. 
Hrouda F., Chlupáčová M., Pokorný J. 2006. Low-field variation of magnetic susceptibility measured by the KLY-4S Kappabridge and KLF-4A magnetic susceptibility meter: Accuracy and interpretational programme. Studia Geophysica et Geodaetica, 50:283-299. https://doi.org/10.1007/ s11200-006-0016-x

Jelinek V. 1978. Statistical processing of magnetic susceptibility measured ingroups of specimens. Studia Geophysica et Geodaetica, 22:50-62.

JelinekV.1981.Characterization ofthemagneticfabricsofrocks.Tectonophysics, 79(3-4):63-67. https://doi.org/10.1016/0040-1951(81)90110-4

López de Luchi M.G., Rapalini A.E., Tomezzoli R.N. 2010. Magnetic fabric andmicrostructures of late Paleozoic granitoids from the north Patagonian Massif: evidence of a collision between Patagonia and Gondwana? Tectonophysics, 494(1-2):118-137. https://doi.org/10.1016/j.tecto.2010.09.003

Lowrie W. 1990. Identification of ferromagnetic minerals in a rock by coercivity and unblocking temperature properties. Geophysical Research Letters, 17:159-162. https://doi.org/10.1029/GL017i002p00159

Martín-Hernández F., Lüneburg C., Aubourg C., Jackson M. 2004. Magnetic Fabric: Methods and Applications. Geological Society, London, Special Publications, 238:1-7. https://doi.org/10.1144/GSL.SP.2004.238.01.01

McReath I., Lins Faraco M.T. 2006. Paleoproterozoic greenstone-granite belts in Northern Brazil and the former Guyana shield - West African Craton Province. Geologia USP Série Científica, 5(2):49-63. http://dx.doi. org/10.5327/S1519-874X2006000100004

Mondal T.K. 2018. Evolution of fabric in Chitradurga granite (south India)-A study based on microstructure, anisotropy of magnetic susceptibility (AMS) and vorticity analysis. Tectonophysics, 723:149-161. https://doi.org/10.1016/j.tecto.2017.12.013

Oriolo S., Oyhantçabal P., Basei M.A.S., Wemmer K., Siegesmund S. 2016. The Nico Pérez Terrane (Uruguay): From Archean crustal growth and connections with the Congo Craton to late Neoproterozoic accretion to the Río de la Plata Craton. Precambrian Research, 280:147-160. https://doi. org/10.1016/j.precamres.2016.04.014

Oyhantçabal P., Cingolani C.A., Wemmer K., Siegesmund S. 2018. The Rio de la Plata Craton of Argentina and Uruguay. In: Siegesmund S., Basei S.M.A., Oyhantçabal P., Oriolo S. (Eds.). Geology of Southwest Gondwana, Regional Geology Reviews. Springer Cham: International Publishing, p. 89-105.

Oyhantçabal P., Derrégibus M., Muzio R., Nardi L.V.S. 1998. The Soca intrusion: a rapakivi granite of Uruguay. Journal of South America Earth Sciences, 11(2):169-178. https://doi.org/10.1016/ S0895-9811(98)00008-X

Oyhantçabal P., Siegesmund S., Wemmer K. 2011. The Río de la Plata Craton: a review of units, boundaries, ages and isotopic signature. International Journal of Earth Sciences, 100:201-220. https://doi.org/10.1007/s00531-010-0580-8

Oyhantçabal P., Sportuno J., Aubet N., Cazaux S., Huelmo S. 2003. Southestern proterozoic of Uruguay: a new stratigraphical proposal to Montevideo formation and its related magmatism. Revista de la Sociedad Uruguaya de Geología, (1):2797-2997.

Oyhantçabal P., Wemmer K., Siegesmund S., Spoturno J. 2006. K-Ar geochronology of the Mosquitos Shear Zone (Piedra Alta Terrane-Río de la Plata craton-Uruguay). In: South American Symposium on Isotope Geology, 5., 2006, Punta del Este. Short Papers ..., p. 149.

Passchier C.W., Trouw R.A.J. 1996. Microtectonics. Springer, Berlin, 289 pp.

Paterson S.R., Vernon R.O.N.H., Tobisch O.T. 1989. A review of criteria for the identification of magmatic and tectonic foliations in granitoids. Journal of Structural Geology, 11(3):349-363. https://doi. org/10.1016/0191-8141(89)90074-6

Peel E., Preciozzi F., 2006. Geochronologic synthesis of the Piedra Alta terrane, Uruguay. In: South American Symposium on Isotope Geology, 5., 2006, Punta del Este. Annals ..., p. 234-237.

Potter D.K., Stephenson A. 1988. Single-domain particles in rocks and magnetic fabric analysis. Geophysical Research Letters, 15(10):1097-1100. https://doi.org/10.1029/GL015i010p01097

Preciozzi F. 1993. Petrography and geochemistry of five granitic plutons from south-central Uruguay. Contribution to the knowledge of the Pedra Alta Terrane. $\mathrm{PhD}$ Thesis, Université de Quebec, Quebec, $189 \mathrm{p}$.

Preciozzi F., Bourne J.H. 1992. Petrography and geochemistry of the Arroyo de la Virgen and Isla Mala plutons, southern Uruguay: Early
Proterozoic tectonic implications. Journal of South American Earth Sciences, 6(3):169-181. https://doi.org/10.1016/0895-9811(92)90006-K

Preciozzi F., Sportuno J., Heinzen W. 1979. Carta Geo-Estructural del Uruguay, a Escala 1:2,000,000 y Memoria Explicativa. Uruguay: Dirección Nacional de Minería y Geología, Ministerio de Industria y Energía del Uruguay, 39 p.

Preciozzi F., Sportuno J., Heinzen W., Rossi P. 1985. Carta Geológica del Uruguay a escala 1:500.000. Uruguay: Dirección Nacional de Minería y Geología, 92 p.

Rapalini A.E., Sánchez Bettucci L., Bagden E., Vásquez C.A. 2015. Paleomagnetic study on mid-Paleoproterozoic rocks from the Río de la Plata craton: Implications for Atlantica. Gondwana Research, 27(4):1534-1549. https://doi.org/10.1016/j.gr.2014.01.012

Rapela C.W., Fanning C.M., Casquet C., Pankhurst R.J., Spalletti L., Poiré D., Baldo E.G. 2011. The Rio de la Plata craton and the adjoining Pan-African/ brasiliano terranes: Their origins and incorporation into south-west Gondwana. Gondwana Research, 20:673-690. https://doi.org/10.1016/j.gr.2011.05.001

Raposo M.I.B., Berquó T.S. 2008. Tectonic fabric revealed by AARM of the proterozoic mafic dike swarm in the Salvador city (Bahia State): São Francisco Craton, NE Brazil. Physics of the Earth and Planetary Interiors, 167(3-4):179-194. https://doi.org/10.1016/j.pepi.2008.03.012

Raposo M.I.B., Pressi L.F., de Assis Janasi V. 2012. Magnetic fabrics and their relationship with the emplacement of the Piracaia pluton, SE Brazil. International Journal of Earth Sciences, 101(3):773-786. https://doi. org/10.1007/s00531-011-0696-5

Rochette P., Jackson M., Aubourg C. 1992. Rock magnetism and the interpretation of anisotropy of magnetic susceptibility. Reviews of Geophysics, 30(3):209-226. https://doi.org/10.1029/92RG00733

Rogers J.J.W. 1996. A history of continents in the past three billion years. Journal of Geology, 104(1):91-107. https://doi.org/10.1086/629803

Sánchez Bettucci L., Peel E., Oyhantçabal P. 2010. Precambrian Geotectonic units of the Río de La Plata craton. International Geology Review, 52(1):50-78. https://doi.org/10.1080/00206810903211104

Santos J.O.S., Hartmann L.A., Bossi J., Campal N., Schipilov A., Piñeyro D., McNaughton N.J. 2003. Duration of the trans-Amazonian cycle and its correlation within South America Based on U-Pb SHRIMP Geochronology of the La Plata Craton, Uruguay. International Geology Review, 45 (1):27-48. https://doi.org/10.2747/0020-6814.45.1.27

Schöpa A., Floess D., de Saint Blanquat M., Annen C., Launeau P. 2015. The relation between magnetite and silicate fabric in granitoids of the Adamello Batholith. Tectonophysics, 642:1-15. https://doi.org/10.1016/j. tecto.2014.11.022

Schipilov A., Iardino G., Bossi J., Piñeyro D. 1998. Gabros hornbléndicos Eo Proterozoicos del Cinturón San José, Uruguay. In: Reunión de Mineralogía y Metalogenía, 4., 1998. Universidad Nacional del Sur, Bahía Blanca, p. 309-316.

Tarling D.H., Hrouda F. 1993. The Magnetic Anisotropy of Rocks. London: Chapman and Hall, 217 p.

Tassinari C.C.G., Macambira M.J.B. 1999. Geochronological provinces of the Amazonian Craton. Episodes, 22(3):174-182.

Teixeira W., D’Agrella-Filho M.S., Hamilton M.A., Ernst R.E., Girardi V.A.V., Mazzucchelli M., Bettencourt J.S. 2013. U-Pb (ID-TIMS) baddeleyite ages and paleomagnetism of 1.79 and 1.59 Ga tholeiitic dyke swarms, and position of the Rio de la Plata Craton within the Columbia supercontinent. Lithos, 174:157-174. https://doi.org/10.1016/j.lithos.2012.09.006

Teruggi M.E., Leguizamón M.A., Ramos V.A. 1988. Metamorfitas de bajo grado con afinidades oceánicas en el basamento de Tandil: su implicancia geotectónica, Provincia de Buenos Aires. Revista Asociación Geológica Argentina, 43:366-374.

Toteu S.F., Van Schmus W.R., Penaye J., Michard A. 2001. New U-Pb and $\mathrm{Sm}-\mathrm{Nd}$ data from north-central Cameroon and its bearing on the pre-Pan African history of central Africa. Precambrian Research, 108(1-2):45-73. https://doi.org/10.1016/S0301-9268(00)00149-2

Trindade R.I.F., Raposo M.I.B., Ernesto M., Siqueira R. 1999. Magnetic susceptibility and partial anhysteretic remanence anisotropies in the magnetite-bearing granite pluton of Tourão, NE Brazil. Tectonophysics, 314(4):443-468.

Verwey E.J.W. 1939. Electronic conduction of magnetite $\left(\mathrm{Fe}_{3} \mathrm{O}_{4}\right)$ and its transition point at low temperatures. Nature, 144:327-328. 